Discussion Paper No. 09-066

\title{
Selectivity in Search Strategies for Innovation - From Incremental to Radical, From Manufacturing to Services
}

Christian Köhler, Wolfgang Sofka, and Christoph Grimpe

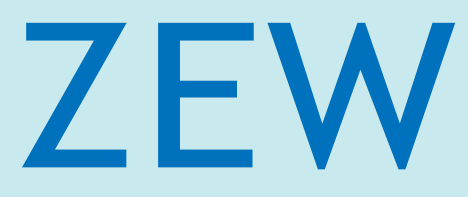

Zentrum für Europäische Wirtschaftsforschung $\mathrm{GmbH}$ Centre for European Economic Research 
Discussion Paper No. 09-066

\title{
Selectivity in Search Strategies for Innovation - From Incremental to Radical, From Manufacturing to Services
}

\author{
Christian Köhler, Wolfgang Sofka, \\ and Christoph Grimpe
}

Download this ZEW Discussion Paper from our ftp server:

ftp://ftp.zew.de/pub/zew-docs/dp/dp09066.pdf

Die Discussion Papers dienen einer möglichst schnellen Verbreitung von neueren Forschungsarbeiten des ZEW. Die Beiträge liegen in alleiniger Verantwortung der Autoren und stellen nicht notwendigerweise die Meinung des ZEW dar.

Discussion Papers are intended to make results of ZEW research promptly available to other economists in order to encourage discussion and suggestions for revisions. The authors are solely responsible for the contents which do not necessarily represent the opinion of the ZEW. 


\section{Non-technical summary}

Research has frequently shown that firm success in technology-driven industries critically depends on the ability to invent and commercialize innovative technology. In this respect, firms with the ability to create new technological knowledge have been praised for generating knowledge internally and combining it with external knowledge sources. However, the process of identifying knowledge to be integrated into the organization's own knowledge base requires that firms deliberately search for and reach out to promising knowledge sources. Search has been characterized as the fundamental mechanism enabling firms to learn, evolve and refocus the organizational knowledge base. In fact, the search strategy, defining direction and priority of boundary-spanning search activities, has been found to substantially impact innovation performance.

In this paper, we shed new light on the relationship between the search strategy of a firm and its innovation performance. We propose that innovation management requires a more nuanced understanding of the nature and effects of search strategies to implement them successfully. Our goal is to add to both academic and practitioner discussions along three major dimensions. First, research on the nature of these search strategies has largely focused on the dimensions of breadth and depth. We argue that the description of search strategies along their breadth and depth underestimates the degree of heterogeneity among the various knowledge sources they encompass. Instead, we argue that management will choose certain directions for the firms' search strategies which target particular knowledge sources (product market, science, suppliers). Second, studies that analyze how firms search typically link search strategies to rather generic and broadly defined innovation outcomes, e.g. counts of patents or new product introductions, sales with new products, etc. We suggest that these targeted search strategies differ with regard to the type of innovation success (incremental vs. radical) they generate. Third, research has mostly concentrated on the manufacturing sector and, more specifically, on high-technology industries. Identifying how firms learn and how the knowledge evolves, though, should not be limited to manufacturing industries, particularly given the increasing importance of service sectors for most modern economies. Therefore, we highlight the distinct nature of innovation in service sectors and the effects they have on the effectiveness of particular search strategies.

Our empirical study is based on a comprehensive dataset of more than 5,000 manufacturing and service firms from five European countries. We find that radical innovations can mainly be realized by science- and supplier-driven search strategies while incremental innovations can be achieved through a market-based search strategy. Innovation success in service firms predominantly benefits from market-driven search. These findings illuminate the searchperformance relationship and highlight the importance of a contingency view on open innovation activities of firms. 


\section{Das Wichtigste in Kürze}

In der Literatur wurde oft darauf hingewiesen, dass der Unternehmenserfolg in technologiebasierten Branchen stark von der Fähigkeit abhängt, innovative Technologien zu entwickeln und $\mathrm{zu}$ vermarkten. In dieser Hinsicht wurden vor allem Firmen hervorgehoben, die es geschafft haben, durch die Kombination von intern geschaffenem Wissen und externen Wissensquellen neues technologisches Wissen zu generieren. Die Identifikation von neuem externen Wissen, das in die eigene Wissensbasis des Unternehmens aufgenommen werden soll, setzt jedoch voraus, dass Unternehmen bewusst nach vielversprechenden Wissensquellen Ausschau halten. Die Suche wird als ein grundlegender Mechanismus beschrieben, durch den Firmen in der Lage sind, zu lernen und ihre Wissensbasis zu erweitern und umzugestalten. Tatsächlich wurde gezeigt, dass die Suchstrategie, welche Richtung und Schwerpunkte der Suchaktivitäten definiert, einen erheblichen Einfluss auf den Innovationserfolg besitzt.

In diesem Beitrag soll die Beziehung zwischen der Suchstrategie eines Unternehmens und dessen Innovationserfolg untersucht werden. Unser Ziel ist es, im Hinblick auf drei Dimensionen zur bestehenden Literatur beizutragen. Erstens hat sich die Forschung zur Art von Suchstrategien im Wesentlichen auf die Dimensionen der Breite und Tiefe beschränkt. Wir argumentieren, dass durch die bloße Unterscheidung zwischen Breite und Tiefe von Suchstrategien der Grad an Heterogenität der verschiedenen Wissensquellen unterschätzt wird. Stattdessen legen wir dar, dass das Management verschiedene Richtungen für die Suchstrategien des Unternehmens wählt, die auf bestimmte Wissensquellen abzielen (Produktmarkt, Wissenschaft, Zulieferer). Zweitens verbinden Studien, die verschiedene Suchstrategien von Firmen untersuchen, diese oft mit relativ allgemein und breit definierten Innovationsergebnissen, wie etwa die Anzahl neuer Patente oder Produkte, Umsatz mit neuen Produkten usw. Wir schlagen vor, dass sich Suchstrategien im Hinblick auf die Art des erzielten Innovationserfolgs (inkrementell vs. radikal) unterscheiden. Drittens hat sich die Forschung bisher hauptsächlich auf das verarbeitende Gewerbe und hier insbesondere auf den Hochtechnologiesektor konzentriert. Untersuchungen darüber, wie Unternehmen lernen und wie Wissen entsteht sollten sich jedoch besonders wegen der zunehmenden Bedeutung des Dienstleistungssektors in modernen Volkswirtschaften nicht nur auf das verarbeitende Gewerbe beschränken. Daher heben wir die besondere Natur von Innovationen im Dienstleistungssektor und deren Auswirkungen auf bestimmte Suchstrategien hervor.

Unsere empirische Auswertung bezieht sich auf einen umfassenden Datensatz mit über 5.000 Unternehmen aus fünf europäischen Ländern. Wir kommen zu dem Ergebnis, dass radikale Innovationen hauptsächlich durch wissenschafts- und zuliefererorientierte Suchstrategien erzielt werden können, während inkrementelle Innovationen besonders durch marktbasierte Suchstrategien entstehen. Der Innovationserfolg von Dienstleistungsunternehmen gründet sich vor allem auf marktorientierte Suchstrategien. Diese Ergebnisse schaffen neue Erkenntnisse über den Zusammenhang zwischen Suche und Innovationserfolg und unterstreichen die Wichtigkeit einer alternativen Sichtweise auf offene Innovationsaktivitäten von Unternehmen. 


\title{
Selectivity in Search Strategies for Innovation - From Incremental to Radical, From Manufacturing to Services
}

\author{
Christian Köhler ${ }^{a}$, Wolfgang Sofka ${ }^{b}$ and Christoph Grimpe ${ }^{a, c}$ \\ ${ }^{a}$ ZEW Centre for European Economic Research, Mannheim (Germany) \\ ${ }^{\mathrm{b}}$ Department of Organisation and Strategy, CentER, CIR, Tilburg University, Tilburg \\ (the Netherlands) \\ ${ }^{\mathrm{c}}$ University of Zurich (Switzerland)
}

\begin{abstract}
The shift towards more open and interconnected innovation activities has been a major topic of recent academic and practitioner discussions. Firms have to connect their in-house R\&D activities with external partners, such as leading customers or universities, to increase the effectiveness of their innovation activities. Hence, management needs to define search strategies for valuable knowledge in its environment. In this paper we argue that search strategies have to reflect the heterogeneity of various knowledge sources with regard to the knowledge they can provide and how these sources can be activated. We hypothesize that search strategies driven by science, suppliers and the product market will contribute differently to innovation success with radically new versus incrementally refined products. We suggest that innovation in service sectors is fundamentally different in nature which influences the performance of different search strategies. We test these hypotheses for a sample of more than 5,000 firms from five European countries. The results support our hypotheses and highlight the potentials and shortcomings of different search strategies.
\end{abstract}

Keywords: Search strategies, service innovation, radical versus incremental innovation

JEL-Classification: L60, O32

Corresponding author:

Christian Köhler

christian.koehler@zew.de

Phone: +49/621/1235-235, Fax: +49/621/1235-170

ZEW Centre for European Economic Research

Department of Industrial Economics and International Management

P.O. Box 1034 43, D-68034 Mannheim, Germany

The authors thank Christian Rammer for invaluable feedback and discussions. This paper has been produced as part of the Innovation Watch project within the Europe INNOVA Initiative, sponsored by the European Commission. 


\section{$1 \quad$ Introduction}

Research has frequently shown that firm success in technology-driven industries critically depends on the ability to invent and commercialize innovative technology (e.g., Katila, 2002; Katila and Ahuja, 2002). In this respect, firms with the ability to create new technological knowledge have been praised for generating knowledge internally and combining it with external knowledge sources (Rosenkopf and Nerkar, 2001). However, the process of identifying knowledge to be integrated into the organization's own knowledge base requires that firms deliberately search for and reach out to promising knowledge sources. Search has been characterized as the fundamental mechanism enabling firms to learn, evolve and refocus the organizational knowledge base. This goes beyond 'local search', which assumes research and development (R\&D) activities to be connected to the firm's previous R\&D (Nelson and Winter, 1982). Literature has emphasized the importance for firms to move beyond local search and to reconfigure the existing knowledge base (Kogut and Zander, 1992; Teece et al., 1997). In fact, the search strategy, defining direction and priority of boundary-spanning search activities, has been found to substantially impact innovation performance (Katila, 2002; Katila and Ahuja, 2002; Laursen and Salter, 2006).

In this paper, we shed new light on the relationship between the search strategy of a firm and its innovation performance. We propose that innovation management requires a more nuanced understanding of the nature and effects of search strategies to implement them successfully. Research on the nature of search strategies has largely focused on the dimensions of overall breadth and depth (e.g. Laursen and Salter, 2006). We argue that the description of search strategies along their breadth and depth underestimates the degree of heterogeneity among the various knowledge sources they encompass. Instead, we suggest that the choice of a search strategy is a selective process. Management will choose certain directions for the firms' search strategies which target particular knowledge sources (product market, science, suppliers). We build his theoretical argument based on the knowledge based view of the firm (Grant, 1996) and draw from the literature on management attention (Ocasio, 1997) and risk perception (March and Shapira, 1987).

Based on this conceptualization of selectivity in the knowledge sources firms target through their search strategies we explore the implications on innovation performance. First, we suggest that these targeted search strategies differ with regard to the type of innovation success (incremental vs. radical) they generate. Secondly, existing research has mostly concentrated on the manufacturing sector and, more specifically, on high-technology industries. Identifying how firms learn and how their knowledge evolves, though, should not be limited to manufacturing industries, particularly given the increasing importance of service sectors for most modern economies. Therefore, we highlight the distinct nature of innovation in service sectors and the effects they have on the performance effects of particular search strategies. All of these aspects have been largely neglected in the discussion of search strategies (e.g. Katila and Ahuja, 2002; Laursen and Salter, 2006; Rosenkopf and Nerkar, 2001) which is why they warrant further investigation. 
Our empirical study is based on a comprehensive dataset of more than 5,000 manufacturing and service firms from five European countries. The paper is organized in seven sections. The next section details our theoretical framework, providing the reference for our hypothesis development in Section 3. Section 4 describes our empirical methods. Results are presented and discussed in the subsequent two sections. Section 7 concludes with limitations of our study and implications for further research.

\section{Theoretical framework}

Our theoretical discussion is grounded in the knowledge-based view of the firm (Grant, 1996; Liebeskind, 1996). It is widely accepted that a firm's ability to innovate is tied to the pool of knowledge available within an organization (e.g., Subramaniam and Venkatraman, 2001; Subramaniam and Youndt, 2005). The generation of new knowledge has traditionally been connected to a firm's in-house research and development (R\&D) activities. Recent literature, however, points to the advantages of combining internal investments with external resources (e.g. Cassiman and Veugelers, 2006) to benefit from complementarities. In other words, firms have begun to open up their innovation processes for external knowledge. This trend of so-called "Open Innovation" allows firms to access and exploit external knowledge while internal resources are focused on core activities (Chesbrough, 2003). Both supply and demand oriented aspects bring firms in a position to acquire knowledge externally. On the one hand, there is an increasing availability of external knowledge, e.g. from universities, customers and specialized suppliers (e.g., von Hippel, 1988; Link and Scott, 2005; Perkmann and Walsh, 2007; van Echtelt et al., 2008). On the other hand, firms are pushed to find new sources for external innovation impulses because of increasing competitive pressures, shorter product life cycles as well as technological opportunities beyond their traditional fields of expertise (e.g., Calantone et al., 1997; Chatterji, 1996; Kleinschmidt and Cooper, 1988; Ojah and Monplaisir, 2003). Several studies have identified positive performance effects from incorporating external knowledge (e.g. Gemünden et al., 1992; Laursen and Salter, 2006; Love and Roper, 2004).

A crucial element in the open innovation activities of firms is the search strategy. A firm's search strategy comprises direction and priorities for external knowledge acquisition and encompasses an "organization's problem-solving activities that involve the creation and recombination of technological ideas" (Katila and Ahuja, 2002: 1184). Consequently, investments in problem-solving activities should result in favorable combinations and linkages of users, suppliers and other relevant actors in the innovation system. Laursen and Salter (2006) discuss the concepts of breadth and depth as important factors for a firm's search strategy. Leiponen and Helfat (forthcoming) complement this view by extending the concept of breadth to innovation objectives. They find the breadth of knowledge sources and of innovation objectives positively influencing innovation success at the firm level. Although a broader set of external sources and innovation objectives reduces the risk of unexpected developments, it has to be taken into account that a firm is constrained in terms of the capacity to absorb external knowledge (Cohen and Levinthal, 1989a, 1990). These limitations 
include the level of overall attention a firm's management can dedicate to these activities (Ocasio, 1997). A proper search strategy should therefore concentrate on certain external sources as a vast number of information sources would hamper selection and in-depth exploration processes (Koput, 1997). Contrary to search breadth, search depth can be described as the extent to which firms draw deeply from the various external sources for innovation impulses (Laursen and Salter, 2006). Both breadth and depth depict a firm's openness for external innovation impulses (Chesbrough, 2003). Studying the UK manufacturing sector, Laursen and Salter (2006) find that the relationship between search breadth and depth and innovation performance has an inverted U-shape. This means that while search efforts initially increase a firm's performance, there is a trade-off from "oversearching" the environment. At a certain threshold it requires too much management attention (Ocasio, 1997) and has a negative effect on innovation performance.

In a similar vein, Katila and Ahuja (2002) focus on search depth and search scope in the search and problem-solving activities of firms from the robotics industry. Contrary to Laursen and Salter (2006), they define search depth as the extent to which a firm reuses existing internal knowledge, while search scope indicates how widely a firm explores externally available knowledge. The latter largely corresponds with search breadth as defined by Laursen and Salter (2006). However, Katila's and Ahuja's (2002) definition of search depth puts a stronger emphasis on exploiting the established knowledge base within the firm. Consistent with the results of Laursen and Salter (2006), Katila and Ahuja (2002) observe an inverted U-shaped relationship between the search effort and innovation performance which again points to the negative consequences of too extensive search activities. They also present evidence that the interaction of search breadth and depth is positively related with innovation performance because it increases the uniqueness of recombinations. A deep understanding of firm-specific knowledge assets that is extended towards a new application (scope) creates unique and more valuable combinations of resources.

\section{$3 \quad$ Hypotheses development}

The conceptualization of a firm's search strategy along the dimensions of its breadth and depth implies that the targeted knowledge is largely homogeneous with regards to its source. Following Laursen and Salter (2006), a firm focusing, for example, solely on lead customer knowledge can be considered to have an equally broad and deep search strategy as a firm concentrating its search for knowledge completely on universities. This assumption may be correct once the external knowledge has entered the firm and is already assimilated with existing knowledge stocks. However, we expect the homogeneity assumption on the knowledge of a search strategy to fail as long as the knowledge remains still unidentified outside the firm's boundaries. This "scanning" stage is crucial for the successful implementation of external knowledge sourcing (Doz et al., 2001). Todorova and Durisin (2007) point out that the transformation of external knowledge is one of the most important steps for absorbing it. This reflects the fact that external knowledge can be assumed to be highly heterogeneous in nature. Literature has characterized the types of knowledge along 
several dimensions, distinguishing tacit and formal (e.g., Cowan et al., 2000; Dyer and Hatch, 2004; Polanyi, 1967), specific and generic (see e.g., Breschi et al., 2000), embodied and disembodied (Romer, 1990), and whether it consists of information or know-how (Kogut and Zander, 1992).

We argue that management will define a firm's search strategy for external knowledge based on its source. Put simply, we propose that management choice is not between breadth and depth but that it provides certain directions for its own research efforts. These directions should reflect the potential value of a knowledge source and how easily it can be accessed and transferred. The focus is thus not so much on the recipient firm's absorptive capacity but rather on the value of the knowledge source. This value assessment reflects the underlying risk of following up on it. These risks may stem from source knowledge that is technologically premature, reflects myopic perspectives or is also readily available to competitors (Frosch, 1996; Katila and Chen, 2008; Mansfield, 1986). Hence, the risk of following up on a particular external knowledge source arises from whether it will lead to a successful invention, whether this invention generates economic returns and whether these returns can be appropriated by the firm marking the investment in the first place. The perception of these risks can be expected to influence the selection of a particular search strategy (March and Shapira, 1987).

What is more, organizational attention within a firm is limited which favors specialization in designing search strategies (Ocasio, 1997). Several authors question the existence of a generally available pool of external knowledge and favor instead a "relational" perspective of knowledge flows (Dyer and Hatch, 2006; Dyer and Singh, 1998; Lane and Lubatkin, 1998). Knowledge flows should therefore not be described as broad diffusion processes but as targeted dyadic exchanges. Hence, the absorptive capacities of the knowledge recipient are not sufficient to explain successful knowledge flows. These depend on the context as well as on the motivation and capability of the source to share (Dyer et al., 2001; Szulanski, 1996, 2000). A firm's search strategy can therefore be expected to be partner or even relationship specific (Dyer and Hatch, 2006). We suggest that the selectivity in firms search strategies stems from differences between knowledge sources in the capabilities required to acquire their knowledge and the risks it entails. We discuss these differences for knowledge sources from science, suppliers and the product market.

The product market side has received considerable attention particularly in the marketing literature as part of the "market orientation" of firms (for a review see Kohli and Jaworski, 1990). This broader conceptualization emphasizes a shift in corporate culture towards creating superior value for customers (e.g. Slater and Narver, 2000). Customers and competitors can be considered the primary elements of a product market driven search strategy. Both groups are necessarily too important to be neglected as their actions have an immediate impact on a firm's sales. Impulses from both groups have been found to propel innovation success. Customers significantly contribute to product innovations even with a high degree of novelty (Lukas and Ferrell, 2000). Moreover, they are especially valuable as knowledge sources when their specific demands are anticipatory for larger market segments in the future (von Hippel, 1988; Beise-Zee, 2001). However, identifying these leading customers has been found to be challenging. Customer knowledge is oftentimes tacit, unarticulated and focused on the 
customer's own myopic needs (Frosch, 1996; Von Zedtwitz and Gassmann, 2002). Literature has therefore cautioned managers not to focus reactively on customers' immediate needs. It is necessary to balance this narrow "consumer-led" approach with proactive measures for identifying long term, latent customer needs (Ketchen et al., 2007; Slater and Narver, 1998, 1999). Competitor knowledge is different with regard to its accessibility. Competitors operate in a similar market and technology context (Dussauge et al., 2000). Their knowledge is oftentimes embodied in the products or services available on the market. That makes it easier to identify relevant aspects and absorb them. However, it limits the opportunities for generating economic returns because of the reduced degree of novelty. Competitor centric search strategies have been found to result more likely in imitations or "me-too" products (Lukas and Ferrell, 2000). Hence, designing and executing successful market-driven search strategies requires specialized competencies. These are most likely to be found in the firm's sales and marketing units because they interact continuously with demanding customers as well as challenging competitors (Asmussen et al., 2009). Experts in the marketing and sales units can be expected to have a developed stock of knowledge which enables them to judge the potential value of a market impulse and the channels to access it.

Science-driven search strategies require a different set of specialized competencies. Universities are the primary producer of fundamentally new knowledge and technologies. The knowledge produced has often times a high degree of novelty which provides important business opportunities (e.g. Cohen et al., 2002). What is more, academic incentive systems for knowledge publication and sharing make university knowledge largely a public good (Perkmann and Walsh, 2007). However, university knowledge is frequently further away from commercial application and requires substantial investments in development to commercialize it (Link et al., 2006; Siegel et al., 2004). Moreover, firms require specialized absorptive capacities to assess and transfer this type of knowledge. Assessing the full value of the often tacit and causally ambiguous knowledge may only be possible through joint research activities in which university and firm scientists develop a mutual understanding and language in practice over time (Laursen and Salter, 2006). A science-driven search strategy should therefore be shaped by the competencies in the firm's own R\&D department (Asmussen et al., 2009). The skills as well as the personal networks of firm scientists and engineers developed through education and training (Adler and Kwon, 2002) are a necessary prerequisite.

Supplier-driven search strategies, though, require specialized competencies in the firm's procurement unit (Asmussen et al., 2009). Suppliers can be important drivers of innovation success (e.g. Pavitt, 1984). They provide new materials, equipment and machinery which can enable the generation of novel products, services or processes. Crucial parts of supplier knowledge are embodied in the products they supply. Then again, these supplies may also be available to competitors limiting the degree of uniqueness that can be derived. Extracting the full potential of these supplier-driven search strategies may require dedicated investments in developing, integrating and refining interactions with leading suppliers. These include early integration into new product development processes, sharing of information or joint research activities which enable firms to establish relation-specific advantages when dealing with suppliers. These advantages are hard to replicate by competitors (Dyer and Hatch, 2006). On the one hand, firms may benefit from accelerated, co-evolutionary knowledge production with 
suppliers (van Echtelt et al., 2008). On the other hand, Kotabe (1990) shows that an overreliance on supplier inputs can limit a firm's own capabilities of adjusting technologies in dynamic environments.

As a consequence, we expect that the effects of targeted search strategies differ with regard to the degree of novelty, i.e. radical versus incremental innovation, as well as with regard to the firm's industry, i.e. manufacturing versus services.

\section{Radical versus incremental innovation}

The innovation capabilities of a firm can be characterized as being radical or incremental (e.g., Dewar and Dutton, 1986; Subramaniam and Youndt, 2005). In this respect, radical innovations are breakthrough or major changes of products, services or processes that may lead to obsolescence of existing designs and technologies (Chandy and Tellis, 2000). They disrupt technological trajectories (Gatignon et al., 2004). Contrary to radical innovations, incremental innovations focus on existing products, services or processes with the objective to refine and reinforce their ability to create value for the firm (Ettlie, 1983) or to improve and exploit existing technological trajectories (Gatignon et al., 2004).

The differences between radical and incremental innovation receive further substantiation when they are linked to the way firms draw on their organizational knowledge base. Abernathy and Clark (1985) note that radical innovations destroy or significantly diminish the value of a firm's knowledge base while incremental innovations augment the applicability of existing knowledge. Therefore, radical innovations are typically based on new knowledge while incremental innovations tend to draw upon refined or reinforced existing knowledge (Subramaniam and Youndt, 2005). Consequently, a lower degree of novelty of external knowledge is presumably associated with the generation of incremental innovation capabilities while a high degree of novelty should increase the opportunities to create radical innovation capabilities.

In this respect, a market-oriented search strategy has been found to be more likely associated with imitations or "me-too" products (Lukas and Ferrell, 2000). Several authors have also warned of "consumer-led" strategies focusing too narrowly on short-term customer needs instead of anticipating demand shifts proactively (Ketchen et al., 2007; Slater and Narver, 1998, 1999). Knowledge that may be accessed through such a search strategy could be rather familiar and does not possess a high degree of novelty. As a result, we would expect a firm's knowledge base to be refined rather than transformed (Subramaniam and Youndt, 2005), leading to the creation of incremental innovations.

Hypothesis 1: Market-driven search strategies propel innovation success of incremental innovations.

In contrast to this, a search strategy based on knowledge from universities or public research institutes can be assumed to provide highly novel knowledge and corresponding opportunities for commercialization (e.g. Cohen et al., 2002). Although university knowledge tends to be publicly available through journal publications resulting in difficulties for firms to appropriate 
the returns from collaborative activities, we believe that firms can differentiate themselves in competition by means of their absorptive capacities resulting in science-driven search strategies. Hence, university knowledge has the potential to transform the organizational knowledge base, leading to the generation of radical innovations.

Hypothesis 2: Science-driven search strategies propel innovation success of radical innovations.

Finally, a supplier-driven search strategy can be another important driver for innovation success (e.g. Pavitt, 1984). On the one hand, firms may use suppliers to learn faster, accelerate the product development process and rely on resources created in a co-evolutionary relationship between the focal firm and its network of suppliers (Dyer and Hatch, 2004; van Echtelt et al., 2008). On the other hand, knowledge produced by suppliers is not necessarily unique since potential competitors may equally benefit from the supplier's expertise. Moreover, Kotabe (1990) finds that firms relying heavily on supplier knowledge may lose relevant manufacturing process knowledge which may cost the firm the opportunity to improve their manufacturing technology in a rapidly changing technological environment. As a result, the effects of a supplier-driven search strategy are ambiguous and lead to two competing hypotheses.

Hypothesis 3a: Supplier-driven search strategies propel innovation success of incremental innovations.

Hypothesis 3b: Supplier-driven search strategies propel innovation success of radical innovations.

\section{Manufacturing versus service sectors}

Existing research on search strategies distinguishing between manufacturing and service sectors is scarce. Most empirical analyses are either explicitly limited to firms in manufacturing (e.g. Laursen and Salter, 2006) or rely on patent statistics to trace knowledge flows (e.g. Katila and Ahuja, 2002). The latter approach is implicitly focused on manufacturing firms as several studies show that firms in manufacturing sectors are significantly more likely to patent than service firms (e.g. Arundel and Kabla, 1998; Harabi, 1995). We argue that innovation processes in service sectors show important differences compared to those in manufacturing firms. These differences should be reflected in the search strategies of service firms.

Many differences between innovation in manufacturing and service sectors can be explained by the very nature of the service business (for a recent review see Paswan et al., 2009). Services are mostly intangible, i.e. no physical object is traded (e. g. Dolfsma, 2004; Gallouj, 2002; Maleri, 1997; Sirilli and Evangelista, 1998). Instead, services are more closely related to a process or a sequence of operations. New services can be designed, tested and introduced quickly and at comparatively low investment levels (Johne and Storey, 1998). Hence, service businesses often generate, convert and introduce product innovations in an incremental and ad-hoc manner (Dolfsma, 2004; Johne and Storey, 1998; Scholich et al., 2006). The high degree of intangibility makes it more difficult to obtain patent protection for newly developed 
services since the majority of services is not eligible for patent protection (e.g. European Patent Convention, Article 52; Dolfsma, 2004). What is more, production and consumption of these services frequently coincide. Literature refers to this feature as "co-terminality" (Sirilli and Evangelista, 1998). The market side is therefore closely interlinked with the production of services, and knowledge exchange should be more frequent and immediate.

These specific features of innovation in services imply that market-driven search strategies should be of dominant importance. Customers participate closely in the provision of services (e. g. Dolfsma, 2004; Gallouj, 2002; Johne and Storey, 1998). This direct connection provides innovative firms with direct access to relevant customer impulses. Even small impulses from customers may generate a high degree of novelty for service innovation, e.g. rental car company enterprise discovered that a significant number of its customers required a rental car when their own was in repair. Hence, the service innovation to pick the customers up provided a crucial source for differentiation from competitors who were largely focusing on customers arriving at airports (Berry et al., 2006). Besides, investment barriers in service sectors are relatively low, i.e. investments into production facilities or logistics should be rather small (Macmillan et al., 1985). Service firms have therefore more opportunities to experiment with new ideas which allow them to integrate and test customer impulses quickly. What is more, the lower investment requirements reduce the risks of potential lock-ins. Even customer impulses which turn out to be myopic and not anticipatory for broader market segments may be served profitably. We conclude:

Hypothesis 4a: Innovation success of radical innovations in service sectors depends primarily on market-driven search strategies.

However, service sectors provide more opportunities to benefit from competitor knowledge. Innovations are less likely to be protected by legal instruments like patents (Lyons et al., 2007). While the costs for imitation of non-patented innovations can still be a barrier for competitors in general (Mansfield et al., 1981), this threshold should be especially low in service sectors. This results in higher potentials for knowledge spillovers which may lead to challenges but also opportunities for quick imitation of new services by competitors. As a consequence, we propose:

Hypothesis 4b: Innovation success of incremental innovations in service sectors depends primarily on market-driven search strategies.

While the service itself is typically intangible in nature, a tangible infrastructure is required to generate it. The role of suppliers for stimulating service innovation through novel equipment is therefore especially pronounced. Firms in supplier-dominated sectors such as personal services (e. g. laundry, repair services) depend on suppliers' innovations in equipment, information and materials (Miozzo and Soete, 2001) which in turn may lead to the development of new services. Barras $(1986 ; 1990)$ showed how in contrast to the classic product cycle model of manufacturing innovation (Abernathy and Utterback, 1978) the application of modern information and communication technology in services led to improved efficiency, quality improvements and eventually to the development of new services. Therefore, knowledge and innovation impulses provided by suppliers are a valuable source for radical innovation in the service sector. We conclude: 
Hypothesis 5: Innovation success of radical innovations in service sectors depends primarily on supplier-driven search strategies.

\section{$4 \quad$ Empirical study}

\subsection{Data}

The empirical part of our study is based on cross-sectional data from the third Community Innovation Survey (CIS-3), which was conducted in 2001 under the co-ordination of Eurostat. The survey covers the innovation activities of enterprises in the EU member states (including some neighboring states) during a three-year period from 1998-2000. What is exceptional about CIS-3 is that it offers representative firm data from all EU member states, which are to a great extend relevant to the questions raised in our study. The micro data of CIS-3 also give information on the two-digit industry code (NACE) of a firm. This means that it is possible to distinguish between firms in manufacturing and service sectors. As the data are anonymized, it is impossible to identify single firms or to trace the exact answers back to the respective firms. Eurostat uses an anonymization process that consists of five steps: pre-processing of the data, micro-aggregation, global recoding, evaluation of the disclosure risk, data suppression and release of the micro-data file (Eurostat, 2005). The usefulness of anonymized data can be evaluated by comparing them with non-anonymized data. In the case of German data, such a comparison of anonymized with non-anonymized data showed a satisfactory performance which indicates that the data can consistently be used to reveal structural relationships among the survey variables (Gottschalk and Peters, 2009).

Although the CIS-3 survey was conducted in all EU member states, the amount of available data is limited to member states that are willing to participate in generating an anonymized database. Our dataset offers micro-aggregated data for five of the EU member states, which makes up a sample of 5,010 observations of enterprises from the following countries: Belgium (640 firms), Germany (1,482 firms), Greece (333 firms), Portugal (500 firms) and Spain (2,067 firms). Industries were identified based on the NACE 2-digit classification and grouped according to the standard industry aggregation by technology level (OECD, 2006). Table 1 provides details on the industries represented in our analysis. 


\section{Table 1: Industry breakdown}

\begin{tabular}{lll}
\hline \hline Industry & NACE Code & Industry Group \\
\hline Manufacturing & & \\
Food and tobacco & $15-16$ & Low-technology \\
Textiles, clothing and leather & $17-19$ & Low-technology \\
Wood / paper / publishing / printing & $20-22$ & Low-technology \\
Chemicals (incl. pharmaceuticals) & 24 & Medium-high-technology \\
Plastics / rubber & 25 & Medium-low-technology \\
Glass / ceramics & 26 & Medium-low-technology \\
Metals & $27-28$ & Medium-low-technology \\
Machinery and equipment & 29 & Medium-high-technology \\
Office and computing machinery & 30 & High-technology \\
Electrical machinery and apparatus & 31 & Medium-high-technology \\
Radio, TV and communication equipment & 32 & High-technology \\
Medical, precision and optical equipment & 33 & High-technology \\
Motor vehicles and trailers & 34 & Medium-high-technology \\
Transport equipment & 35 & Medium-high-technology \\
Manufacturing n.e.c. (e.g. furniture, & $36-37$ & Low-technology \\
sports equipment and toys) & & \\
Services & & \\
Transport and storage (land, water, air) & $60-63$ & Low knowledge intensive \\
Post and Telecommunications & 64 & Knowledge intensive \\
Financial intermediation & $65-67$ & Knowledge intensive \\
Computer, engineering and R\&D services & $72,73,74.2$, & Knowledge intensive \\
& 74.3 & \\
\hline \hline
\end{tabular}

A major benefit of CIS-3 lies in the provision of direct, importance-weighted measures for a comprehensive set of variables for a firm's innovation management (Criscuolo et al., 2005). General managers, heads of R\&D departments or innovation management are asked directly if and how they are able to generate innovations. Such immediate information on processes and outputs can be added to traditional measures for innovation such as patents (Kaiser, 2002; Laursen and Salter, 2006). That seems to be especially relevant for our research question as service firms have a lower propensity to patent their innovations.

Innovation surveys like CIS rely on firm's self-reporting. This might raise quality issues regarding administration, non-response and response accuracy (for a recent discussion see Criscuolo et al., 2005). However, the implementation of the survey is designed to limit possible negative effects. The fact that the survey is conducted via mail prevents certain shortcomings and biases of telephone interviews (for a discussion see Bertrand and Mullainathan, 2001). Moreover, the survey is accompanied by extensive pre-testing and piloting in various countries, industries and firms with regards to interpretability, reliability and validity (Laursen and Salter, 2006). In order to improve response accuracy, the questionnaire offers detailed definitions and examples. 


\subsection{Variables and method}

\section{Measuring success of radical and incremental innovations}

Several authors have introduced different concepts for measuring innovation success (for an overview see Hagedoorn and Cloodt, 2003). One possibility is to use innovation inputs (R\&D expenditures) as an indicator for innovation efforts and (indirectly) innovation success. Another way is to look at the outcome of innovative efforts, such as patents, new processes, services and/or products. The latter is the perspective that we choose for our study. Furthermore, we distinguish between radical and incremental innovations by considering the degree of novelty. We refer to a product or service to be a radical innovation if it is not just new to the firm but to its overall market: In contrast, we consider a product or service to be an incremental innovation if it is only new to the firm, but with already existing alternatives on the market.

The success of an innovation largely depends on market acceptance. For this reason we define innovation success as the share of sales achieved with products/services new to the market on one hand and the share of sales achieved with products/services new to the firm on the other. ${ }^{1}$ For ease of presentation we will subsequently limit the terminology for innovation outputs to the terms "market novelties" for products and/or services new to the market and "firm novelties" for products and/or services only new to the firm. There is not implicit or explicit distinction between innovative products and services beyond the industry classification.

\section{Capturing search strategies}

Measuring knowledge spillovers is a challenging task since they leave no paper trail. Several studies use patent statistics and subsequent citations to capture them (e.g., Galunic and Rodan, 1998; Rosenkopf and Nerkar, 2001). However, such an approach is not always appropriate, as "not all inventions are patentable, not all inventions are patented" (Griliches, 1990: p. 1669). Moreover, the distribution of patenting firms is often heavily skewed. This is for example demonstrated by Bloom and van Reenen (2002). In their study, 72 percent of the sample of almost 60,000 patents by UK firms, originate from just twelve companies. Patenting implies the disclosure and codification of knowledge in exchange for protection (Gallini, 2002). The majority of valuable knowledge may therefore never be patented. Moreover, when relying on patent statistics the opportunities to identify distinct search strategies are limited, because they do not offer any information on the relationships between the two firms identified in the patents (e.g. whether they are customers or competitors). Therefore, we use survey questions to gain information about external knowledge sources. Importance-weighted answers indicate the value of their contribution. More precisely, respondents are asked to evaluate the importance of the main sources for their innovation activities on a 4-point Likert scale ranging from "not used" to "high". We use information

1 Not all of a firm's "new to the market"-products are necessarily "new to the world" but only new to the firm's specific market. 
about seven different sources: suppliers, customers, competitors, universities, public research institutes, professional exchanges (e.g. conferences), as well as exhibitions and fairs. In a similar setting, Laursen and Salter (2006) generate indices for the breadth and depth of a firm's search strategy based on these questions. Breadth is measured as the number of different sources used while depth is measured as the number of highly important sources. We deviate from their approach in order to identify targeted search strategies.

We argue that R\&D managers develop targeted search strategies with a certain direction. This is in contrast to Laursen and Salter (2006) who assume that search strategies are defined based on their search and depth, ignoring their direction. We inspect the correlations between the several knowledge sources as shown in Table 2 and find that customers and competitors, universities and public research institutes, and professional exchanges and exhibitions/fairs are correlated with each other. This observation gives reason to the assumption that firms apply targeted search strategies. We therefore apply a principal component factor analysis in order to identify underlying factors. The data appear to be suitable (Cronbach's alpha scale reliability coefficient: 0.70; Kaiser-Meyer-Olkin measure of sampling adequacy: 0.69). We identify three factors with an eigenvalue higher than one. We conduct an orthogonal varimax rotation in order to interpret the factors with respect to their informational content. The orthogonality assumption of the factors is tested through a likelihood ratio test which confirms the independence of all factors with an error probability far below 1\% (Kaiser and Rice, 1974). Factor loadings identify three individual factors distinctively (above 0.69), as illustrated in Table 3.

Table 2: Correlation matrix of knowledge sources

\begin{tabular}{|c|c|c|c|c|c|c|c|}
\hline & Supplier & Customer & Competitor & University & $\begin{array}{c}\text { Public } \\
\text { Research } \\
\text { Institute }\end{array}$ & $\begin{array}{c}\text { Professio- } \\
\text { nal } \\
\text { Exchange }\end{array}$ & $\begin{array}{c}\text { Exhibitions } \\
\text { and Fairs }\end{array}$ \\
\hline Supplier & 1 & & & & & & \\
\hline Customer & 0.120 & 1 & & & & & \\
\hline Competitor & 0.164 & 0.441 & 1 & & & & \\
\hline University & 0.131 & 0.206 & 0.176 & 1 & & & \\
\hline $\begin{array}{l}\text { Public Research } \\
\text { Institute }\end{array}$ & 0.130 & 0.167 & 0.142 & 0.572 & 1 & & \\
\hline Professional Exchange & 0.223 & 0.206 & 0.265 & 0.356 & 0.291 & 1 & \\
\hline Exhibitions and Fairs & 0.265 & 0.262 & 0.305 & 0.202 & 0.204 & 0.545 & 1 \\
\hline $\mathrm{N}$ & 5,010 & & & & & & \\
\hline
\end{tabular}

The retained factors reflect our conceptualization of search strategies defined along specific search directions instead of rather broadly defined breadth and depth. The first factor is characterized by scientific contributions to innovation processes (public research institutes and universities). Therefore we will refer to this factor as "science-driven search strategy". Suppliers, professional exchanges, and exhibitions/fairs load highly positive on the second 
factor. Hence, we interpret this factor as "supplier-driven search strategy". In contrast, the third factor reflects a considerable contribution to innovation processes coming from the firms' market environment (customers and competitors). We interpret this factor accordingly as "market-driven search strategy". We will use the three derived factor scales as focus variables to test our hypotheses empirically.

Table 3: Results of the principal component factor analysis: Factor loadings after varimax rotation

\begin{tabular}{l|ccc|cc}
\hline \hline & Factor 1 & Factor 2 & Factor 3 & Uniqueness & KMO \\
\hline Supplier & & 0.704 & & 0.505 & 0.851 \\
Customer & & & 0.846 & 0.264 & 0.704 \\
Competitor & & & 0.808 & 0.301 & 0.718 \\
University & 0.866 & & & 0.224 & 0.646 \\
Public Research Institute & 0.869 & & & 0.232 & 0.654 \\
Professional Exchange & & 0.694 & & 0.369 & 0.712 \\
Exhibitions and Fairs & & 0.763 & & 0.333 & 0.695 \\
\hline Cronbach's alpha & 0.73 & 0.61 & 0.61 & & 0.70 \\
Overall & & & & & 0.694 \\
\hline \hline
\end{tabular}

Factor loadings below 0.5 are excluded from the table.

\section{Control variables}

We include several control variables in our empirical model to account for other factors that may influence the estimation results. Obviously, the success of a firm's innovation activities depends crucially on the level of its investments into research and development. These inhouse R\&D investments have been found to form a firm's absorptive capacity for identifying, assimilating and exploiting external knowledge (Cohen and Levinthal, 1989b, 1990). Hence, we include $R \& D$ intensity measured by $R \& D$ expenditures as a share of sales. Furthermore, valuable knowledge is often times the result of accumulated $R \& D$ over time which typically requires a dedicated $R \& D$ department. We include a dummy control variable on whether the company performs R\&D continuously. As firm's innovation success may be affected by the availability of resources we control for a liability of size or smallness by adding the firm's sales from the start of the reporting period (1998) in logs. A firm's degree of internationalization is captured by the ratio of exports to total sales. As our observations stem from various European countries, it is necessary to control for effects of the national regulation environment as well as peculiarities of the innovation system. This is done by incorporating country dummy variables into the regression. If a firm is part of a group, it can spread certain functions among subsidiaries or draw from their resources. We therefore add a dummy variable to control for this fact. Besides, some firms may strictly invest in process innovation. The innovation success of these activities cannot be accounted for. We thus add a dummy variable for process innovators. 


\section{Estimation strategy}

We estimate two separate empirical models for both dependent variables: share of sales with firm novelties and share of sales with market novelties. The coefficients of the scales of the targeted search strategies allow the test of hypotheses 1, 2 and 3. We run the same estimations on a sub-sample of service firms only to test hypotheses $4 \mathrm{a} / \mathrm{b}$ and 5 . Our dependent variables are shares and therefore censored between 0 and 1 with significant fraction of observations with zero values. We address this issue by estimating Tobit models. We test the consistency of these estimations subsequently through additional model specifications.

We benefit from a comprehensive dataset that does not limit the empirical findings to a particular firm size, industry or country setting. Then again, this induces additional layers of heterogeneity to the dataset which may not be completely captured by control variables. Most standard regression models require homoscedasticity for consistent estimation results. This implies the assumption that the error term of an estimation is largely independent from the exogenenous variables. Put simply, the variance of the random variable is assumed to be the same no matter whether observations stem from large or small firms, differ by industry or country. If this is not the case, estimations might suffer from heteroscedasticity ${ }^{2}$. Heteroscedastic datasets may lead to an underestimation of the variance in an empirical model and subsequently to a lower threshold for the identification of significant results. Given the nature of our dataset, we consider it necessary to test for homoscedasticity. We apply Lagrange Multiplier tests on the basis of the homoscedastic models to check if firm size, industry and location of a firm cause heteroscedasticity ${ }^{3}$. The results of the LM-test which are shown in Table 4 reject homoscedasticity in all model specifications.

Table 4: LM-test-statistics on heteroscedasticity for all Tobit models

\begin{tabular}{|c|c|c|c|c|c|c|}
\hline \multirow[t]{3}{*}{ Tested Variables } & \multicolumn{6}{|c|}{ LM value } \\
\hline & \multicolumn{3}{|c|}{ Full sample } & \multicolumn{3}{|c|}{ Service sample } \\
\hline & $\begin{array}{l}\text { Critical } \\
\text { value } \\
\chi^{2}(\mathrm{df}, \alpha)^{\mathrm{a})}\end{array}$ & $\begin{array}{c}\text { Share of sales } \\
\text { with market } \\
\text { novelties }\end{array}$ & $\begin{array}{c}\text { Share of sales } \\
\text { with firm } \\
\text { novelties }\end{array}$ & $\begin{array}{l}\text { Critical } \\
\text { value } \\
\chi^{2}(\mathrm{df}, \alpha)^{\mathrm{a})}\end{array}$ & $\begin{array}{c}\text { Share of sales } \\
\text { with market } \\
\text { novelties }\end{array}$ & $\begin{array}{c}\text { Share of sales } \\
\text { with firm } \\
\text { novelties }\end{array}$ \\
\hline Firm size & 6.634 & $118.545^{* * *}$ & $52.9836^{* * *}$ & 6.634 & $256.894 * * *$ & $104.051 * * *$ \\
\hline Country dummies & 13.276 & $76.764 * * *$ & $113.538 * * *$ & 13.276 & $224.273 * * *$ & $151.154 * * *$ \\
\hline Industry dummies & 15.086 & $20.107 * * *$ & $16.835 * * *$ & 6.634 & $121.781 * * *$ & $57.462 * * *$ \\
\hline
\end{tabular}

Thus we include firm size, country dummies and industry dummies into heteroscedastic regressions where we consider the variance $\sigma_{i}^{2}$ of observation $i$ being of the form

${ }^{2}$ _ These variables have frequently been shown to cause heteroscedasticity in this setting (see e. g. Aschhoff and Schmidt, 2006; Czarnitzki and Toole, 2007).

3 See Greene, 2002, p. 698-700 for details. 
$\sigma_{i}=\sigma \exp \left(z_{i}^{\prime} a\right) . z$ represents the vector of variables in the heteroscedasticity term while $a$ denotes the vector of additional coefficients to be estimated. Consequently we only present heteroscedasticity-consistent coefficients.

Besides, we inspect the dataset for issues arising from multicollinearity by calculating both pair-wise correlations and variance inflation factors. The dataset shows no particularly high degree of multicollinearity by any conventionally applied standard in the literature (Chatterjee and Hadi, 2006). The correlation table and the variance inflation factors are presented in Appendix D.

\section{$5 \quad$ Results}

\section{Descriptive statistics}

Table 5 shows interesting differences in firm's search strategies with respect to innovation success. We conduct significance tests on mean differences between firms with above average usage of a certain search strategy compared with the rest. Firms using science-driven search strategies above average exhibit a significantly higher share of sales with both market and firm novelties. In contrast to that, we do not observe a significant difference in neither radical nor incremental innovation success for firms engaging predominantly in a supplier-driven search strategy. A somewhat mixed pattern is revealed by firms using mainly a market-driven search strategy. We find a higher share of sales with firm novelties while there is no difference observable in the share of sales with firm novelties compared to firms using a market-driven search strategy below average.

Table 5: Descriptive statistics differentiated by search strategy

\begin{tabular}{|c|c|c|c|c|c|c|c|c|c|}
\hline & \multicolumn{2}{|c|}{ All firms } & \multicolumn{3}{|c|}{$\begin{array}{l}\text { Science-driven search } \\
\text { used above average }\end{array}$} & \multicolumn{2}{|c|}{$\begin{array}{l}\text { Supplier-driven search } \\
\text { used above average }\end{array}$} & \multicolumn{2}{|c|}{$\begin{array}{l}\text { Market-driven search } \\
\text { used above average. }\end{array}$} \\
\hline & Mean & Std. Dev. & Mean & & Std. Dev. & Mean & Std. Dev. & Mean & Std. Dev. \\
\hline $\begin{array}{l}\text { Share of sales with } \\
\text { market novelties }\end{array}$ & 0.101 & 0.180 & 0.110 & $\star * *$ & 0.179 & 0.104 & 0.180 & 0.104 & 0.177 \\
\hline $\begin{array}{l}\text { Share of sales with } \\
\text { firm novelties }\end{array}$ & 0.159 & 0.236 & 0.168 & ** & 0.229 & 0.159 & 0.234 & $0.169 \quad \star \star \star$ & 0.231 \\
\hline
\end{tabular}

T-test are computed in comparison to firms using the respective search strategy below the average. Descriptive statistics of the full list of variables is presented in Appendix A.

However, firms differ along several dimensions with regard to the choice of a search strategy. Appendix A provides descriptive statistics for the full set of variables. Again, we test for significant mean differences between firms with an above average use of a particular search strategy compared to their below average counterparts. All search strategies have in common that they are significantly more likely to be chosen by firms with higher R\&D spending and continuous R\&D activities. This supports the literature on the merits of firms own R\&D investments for building absorptive capacities for external knowledge (Cohen and 
Levinthal, 1989b, 1990). Firms with above average search strategies are also significantly larger (in terms of sales) reflecting the availability of resources do develop an active search for external knowledge.

Firms with above average science- and/or market-driven search strategies are significantly more internationalized (measured as export share of sales) and part of a company group. Process innovators are more likely to focus on science- and/or supplier-driven search strategies. With regard to differences across industries, two patterns emerge. Supplier-driven search strategies are significantly more attractive to firms in low-tech manufacturing. However, as the knowledge intensity of the industry increases, both science- and marketdriven search strategies are significantly more appealing to firms. Interestingly, this trend emerges in both manufacturing and service sectors. This provides some initial evidence that search for knowledge in services sectors may not be limited to the market side. However, these structural differences can only be separated through a multivariate analysis.

\section{Regression results}

Table 6 shows the results of the Tobit model estimations. As outlined before, we correct the variance in each model to account for the effects of heteroscedasticity and test the outcomes of this correction successfully. We estimate two separate models for each dependent variable. Column I and II show the estimation results for the full sample. The results in column I show that success with incremental innovations, as measured by the share of sales with firm novelties, is positively affected by market-driven search strategies. This supports hypothesis 1 which proposes a positive relationship between market-driven search strategies and incremental innovation success. We find a positive relationship between success with radical innovations, as measured by the share of sales with market novelties, both for science- and supplier-driven search strategies. Thus, we find support for hypotheses 2 and $3 \mathrm{~b}$ which state that science- and supplier-driven search strategies propel success with radical innovations.

We test these relationships also for the sub-sample of service firms. The results of the estimations are presented in column III and IV. In contrast to the full sample, a different picture emerges. The share of sales generated with firm novelties (column III) is significantly increased by the market-driven and science-driven search strategies while a supplier-driven search strategy does not exert a significant impact. Therefore, success with incremental innovation is fostered by focusing on scientific and market sources of external knowledge in service sectors. Considering the sales with market novelties (column IV), we find that service firms gain through all different directions of search. The coefficients of science-driven, supplier-driven and market-driven search strategies are positive and significant. As we find a robust and strong positive relationship of a market-driven search strategy on innovation success - may it be radical or incremental innovation - the results support hypotheses 4a and 4b. The significant, positive effect from supplier-driven search strategies supports hypothesis 5 .

\section{Table 6: Results of Tobit estimations}




\begin{tabular}{|c|c|c|c|c|}
\hline & $\begin{array}{c}\text { Share of sales } \\
\text { with firm } \\
\text { novelties }\end{array}$ & $\begin{array}{c}\text { Share of sales } \\
\text { with market } \\
\text { novelties }\end{array}$ & $\begin{array}{c}\text { Share of sales } \\
\text { with firm } \\
\text { novelties }\end{array}$ & $\begin{array}{c}\text { Share of sales } \\
\text { with market } \\
\text { novelties }\end{array}$ \\
\hline & I & II & III & IV \\
\hline Science- driven search strategy (scale) & $\begin{array}{l}0.017 \\
(0.025)\end{array}$ & $\begin{array}{c}0.036 * \\
(0.020)\end{array}$ & $\begin{array}{c}0.095 * * \\
(0.048)\end{array}$ & $\begin{array}{c}0.102 * * \\
(0.040)\end{array}$ \\
\hline Supplier-driven search strategy (scale) & $\begin{array}{l}0.019 \\
(0.024)\end{array}$ & $\begin{array}{c}0.036^{*} \\
(0.021)\end{array}$ & $\begin{array}{l}-0.022 \\
(0.044)\end{array}$ & $\begin{array}{l}0.079 * * \\
(0.040)\end{array}$ \\
\hline Market-driven search strategy (scale) & $\begin{array}{c}0.121 * * * \\
\quad(0.021)\end{array}$ & $\begin{array}{l}0.028 \\
(0.018)\end{array}$ & $\begin{array}{c}0.088 * * \\
(0.039)\end{array}$ & $\begin{array}{c}0.073 * * \\
(0.035)\end{array}$ \\
\hline Share of internal R\&D exp. of sales (ratio) & $\begin{array}{c}0.124^{*} \\
(0.069)\end{array}$ & $\begin{array}{c}0.306 * * * \\
(0.061)\end{array}$ & $\begin{array}{l}0.094 \\
(0.082)\end{array}$ & $\begin{array}{c}0.223 * * * \\
(0.070)\end{array}$ \\
\hline Continuous R\&D activities (d) & $\begin{array}{c}0.031 * * * \\
\quad(0.011)\end{array}$ & $\begin{array}{c}0.081 * * * \\
\quad(0.009)\end{array}$ & $\begin{array}{c}0.032 * \\
(0.020)\end{array}$ & $\begin{array}{c}0.086^{* * * *} \\
\quad(0.018)\end{array}$ \\
\hline Share of sales w/ exports (ratio) & $\begin{array}{l}0.017 \\
(0.019)\end{array}$ & $\begin{array}{c}0.043 * * * \\
(0.016)\end{array}$ & $\begin{array}{c}-0.053 \\
(0.044)\end{array}$ & $\begin{array}{l}-0.041 \\
(0.044)\end{array}$ \\
\hline Sales $1998(\log )$ & $\begin{array}{l}0.003 \\
(0.003)\end{array}$ & $\begin{array}{l}0.002 \\
(0.002)\end{array}$ & $\begin{array}{r}-0.001 \\
(0.004)\end{array}$ & $\begin{array}{l}0.001 \\
(0.004)\end{array}$ \\
\hline Part of company group (d) & $\begin{array}{l}-0.007 \\
(0.011)\end{array}$ & $\begin{array}{l}0.003 \\
(0.009)\end{array}$ & $\begin{array}{c}0.033^{*} \\
(0.019)\end{array}$ & $\begin{array}{r}-0.023 \\
(0.017)\end{array}$ \\
\hline Process innovation $(\mathrm{d})$ & $\begin{array}{c}-0.057 * * * \\
(0.010)\end{array}$ & $\begin{array}{c}-0.003 \\
(0.009)\end{array}$ & $\begin{array}{c}-0.047 * * * \\
(0.018)\end{array}$ & $\begin{array}{l}-0.019 \\
(0.017)\end{array}$ \\
\hline Constant & $\begin{array}{c}-0.105 * * \\
(0.048)\end{array}$ & $\begin{array}{c}-0.224 * * * \\
\quad(0.042)\end{array}$ & $\begin{array}{l}0.017 \\
(0.071)\end{array}$ & $\begin{array}{c}-0.156 * * \\
(0.065)\end{array}$ \\
\hline Country dummies included & yes & yes & yes & yes \\
\hline Industry dummies included & yes & yes & yes & yes \\
\hline $\begin{array}{l}\text { Wald - Test on joint significance of } \\
\text { industry dummies }\end{array}$ & $\begin{array}{c}\mathrm{W}\left(\chi^{2}(10)\right)= \\
19.81^{* *}\end{array}$ & $\begin{array}{l}\mathrm{W}\left(\chi^{2}(10)\right)= \\
44.45 * * *\end{array}$ & $\begin{array}{l}\mathrm{W}\left(\chi^{2}(2)\right)= \\
2.70\end{array}$ & $\begin{array}{l}\mathrm{W}\left(\chi^{2}(2)\right)= \\
9.26^{* * *}\end{array}$ \\
\hline Aldrich-Nelson Pseudo-R ${ }^{2}$ & 0.21 & 0.26 & 0.23 & 0.33 \\
\hline Log likelihood & -2208.448 & -1771.362 & -609.525 & -530.806 \\
\hline No. of observations & 5010 & 5010 & 1401 & 1401 \\
\hline LR - Test on heteroscedasticity & $\begin{array}{l}\operatorname{LR}\left(\chi^{2}(10)\right)= \\
217.661 * * *\end{array}$ & $\begin{array}{l}\operatorname{LR}\left(\chi^{2}(10)\right)= \\
327.988 * * *\end{array}$ & $\begin{array}{l}\operatorname{LR}\left(\chi^{2}(6)\right)= \\
96.511 * * *\end{array}$ & $\begin{array}{l}\operatorname{LR}\left(\chi^{2}(6)\right)= \\
100.999 * * *\end{array}$ \\
\hline
\end{tabular}

(d) Dummy variable, $* \mathrm{p}<0.10, * * \mathrm{p}<0.05, * * * \mathrm{p}<0.01$; standard errors in parentheses.

Search strategy scales are rescaled between 0 and 1 . Coefficients of industry and country dummies are presented in Appendix B. Heteroscedasticity terms include firm size as measured by sales in $1998(\log ), 4$ country dummies and 5 industry dummies (Service sample: 1 industry dummy).

Regarding our control variables, we find that performing R\&D continuously has a positive impact on a firm's innovation success in both samples. The R\&D intensity affects the radical innovation success positively while we find no effect for incremental innovation success. Hence, our results confirm the importance of both long-term R\&D engagements and the amount of funds spent on R\&D for radical innovation success while incremental innovation success is facilitated by continuous engagement in $R \& D$ activities. The remaining control variables in our regression show the expected signs. Firm size measured by the log of sales in 1998 has a negative impact on the innovation success in all model specifications reflecting the fact that the share of new products relative to sales in a small firm is typically higher than in a large firm (Rammer et al., 2009). If firms are process innovators they have to allocate limited personnel and financial resources to both the development of new processes and new products, respectively. Therefore, the innovation success with sales will decrease which is 
supported by our findings of negative effects of process innovation. However, this holds only for the models of incremental innovation. Internationalization as measured by the share of exports of sales has a positive effect on radical innovation success in the full sample while there is no significant effect for incremental innovation success. This may reflect incentives to engage in radical innovation due to high competition pressure in international markets in manufacturing industries. In contrast to that, no significant effect of internationalization can be found in the service sample. This result may indicate the local boundaries of services since they are typically not exportable but have to be provided in close interaction with the client. No effect among all model specifications can be found for a firm being part of a company group.

\section{Consistency checks}

We conduct further estimations to check the consistency of our results. Both Laursen and Salter (2006) and Katila and Ahuja (2002) identify inverse U-shaped relationships between the breadth and depth of a firm's search strategy and innovation success. We test for nonlinear relationships of our targeted search strategies by including their squared values in the estimation equation (see Appendix C). The comparison appears to be especially relevant as Laursen and Salter (2006) rely on the same variables for capturing a firm's search strategy. Our results indicate that the finding of an inverse U-shape is limited to the science-driven search strategy and its relationship to the share of sales generated with firm novelties within the subsample of service firms. We suspect that the positive linear effect in Laursen and Salter (2006) stems from combinations of external knowledge sources within the same targeted search strategy, e.g. firms which combine customer and competitor knowledge but do not access external knowledge beyond that. This would explain why the effect of adding an additional knowledge source requiring different competencies (e.g. university knowledge) lowers the effectiveness of the overall search strategy. Hence, an inverse U-shaped relationship would emerge. We add interaction terms between our targeted search strategy scales to explore this issue further. However, no significant effects can be found when including the interaction terms. ${ }^{4}$

\section{Discussion}

We conduct this study to provide a more nuanced perspective on the nature of firm's search strategies for external knowledge and what effects innovation managers can expect from applying them. We argue conceptually that search strategies are not homogeneous with regard to the sources they encompass. In that sense, conceptualizations describing search strategies along the dimensions of breadth and depth (Katila and Ahuja, 2002; Laursen and Salter, 2006) may underestimate the degree of heterogeneity among different knowledge sources. What is more, we integrate two additional elements into the stream of research on open innovation and search strategies. First, we focus on varying degrees of novelty in firm's open innovation

\footnotetext{
$4 \quad$ Results are available from the authors upon request.
} 
performance. Some knowledge sources can be expected to provide knowledge with a higher degree of novelty providing more opportunities for radical innovation than others. Second, the nature of innovation activities in service sectors differs significantly from manufacturing sectors. Hence, the particularities of services firms can be expected to be reflected in the success of their search strategies. We test our hypotheses empirically for a comprehensive sample of more than 5,000 firms from five different countries in Europe and find support for most of them. Therefore, conclusions can be drawn with implications for both academic and management audiences.

From a research perspective, we introduce the notion of selectivity in firm's search strategies. While the research on diversity (breadth) versus focus (depth) in a firm's search strategy has enriched our understanding of the value of both elements of a search strategy, it does not provide much guidance on which knowledge sources to combine in a broad strategy and which ones to emphasize for depth. We find strong support for our theoretical argument that management should choose a certain direction for a firm's search strategy. Sciencedriven, supplier-driven and market-driven search strategies differ significantly in the kind of knowledge they can provide and the way they can be accessed by the firm. They can therefore not be assumed to be substitutive. This is reflected in the value which they can provide in different sectors and with respect to different degrees of novelty. Several studies highlight the increasing importance of service sectors for most modern economies (e.g. Sirilli and Evangelista, 1998). However, empirical tests of open innovation search strategies have primarily focused on manufacturing sectors (Katila and Ahuja, 2002; Laursen and Salter, 2006; Rosenkopf and Nerkar, 2001). We find that market-driven search strategies are even more important for service firms compared to manufacturing firms. This can be traced back to the literature on co-terminality of production and consumption in service firms. Market-driven search strategies provide unique knowledge leading to radical innovations in service sectors. This mechanism cannot be supported in manufacturing firms. A too narrow focus on the role of competitors and customers in service sectors may underestimate the equally important role of knowledge from science and suppliers for the successful development of market novelties. Science- and supplier-driven search strategies also propel manufacturing firms' innovation success with radically new products. Market driven search strategies include the danger of over-emphasizing short-term customer needs and imitations of already existing products. Hence, our findings extend existing literature (e.g. Slater and Narver, 1998) and provide pathways for expanding it further. A primary strategy of avoiding "customer-led" traps of incremental innovation may rest in extending a firm's knowledge pool with search strategies directed at leading universities and specialized suppliers.

From a management perspective several implications can be derived. First, a search strategy focusing narrowly on customers and competitors cannot be expected to provide radically new innovations outside the service sector. Then again, market-driven search strategies provide incremental innovations which may still be profitable without entailing the increased risk of the radical ones. Second, innovation managers of service firms have strong incentives to broaden their portfolio of promising sources of knowledge outside of the firm. These can be found at universities and from suppliers alike. From the management perspective this may require increased resource commitments at procurement and $R \& D$ units to generate the 
necessary channels for assessing and transferring their particular knowledge. Third, we find strong evidence that firms benefit strongly from their own investments in knowledge production through in-house $\mathrm{R} \& \mathrm{D}$, especially when engaging continuously and benefiting from accumulated knowledge. Hence, open innovation search strategies appear to be complementary with in-house knowledge production instead of substitutive in nature.

\section{$7 \quad$ Concluding remarks and further research}

Our research benefits from a comprehensive cross-country dataset which allows us to draw conclusions beyond a certain industry or country context. However, we see room for improvement which may provide pathways for future research. The effects of investments in $\mathrm{R} \& \mathrm{D}$ and open innovation networks may reach their full potential over the long run. Hence, longitudinal studies may help to test and substantiate some of our cross-sectional findings. Besides, qualitative studies may provide further in-depth insights into the mechanisms underlying the different search strategies. This may be especially relevant with regard to how legitimacy and trust can be established and how these mechanisms differ across varying knowledge sources. Finally, manufacturing firms increasingly extend their business activities to services. Investigating the changes in their search strategies underlying these shifts in business models may be a fruitful direction for further research. 


\section{References}

Abernathy, W.J. and K. Clark (1985), Innovation: Mapping the Winds of Creative Destruction, Research Policy 14, 3-22.

Abernathy, W.J. and J.M. Utterback (1978), Patterns of Innovation in Industry, Technology Review 80 (7), 40-47.

Adler, P.S. and S.-W. Kwon (2002), Social Capital: Prospects for a New Concept, Academy of Management Review 27 (1), 17-40.

Arundel, A. and I. Kabla (1998), What Percentage of Innovations are Patented? Empirical Estimates for European Firms, Research Policy 27, 127-141.

Aschhoff, B. and T. Schmidt (2006), Empirical Evidence on the Success of R\&D Cooperation - Happy together?, ZEW Discussion Paper No. 06-059, Mannheim.

Asmussen, C.G., T. Pedersen and C. Dhanaraj (2009), Host-country Environment and Subsidiary Competence: Extending the Diamond Network Model, Journal of International Business Studies 40 (1), 42-57.

Barras, R. (1986), Towards a Theory of Innovation in Services, Research Policy 15 (4), 161173.

Barras, R. (1990), Interactive Innovation in Financial and Business services: The Vanguard of the Service Revolution, Research Policy 19 (3), 215-237.

Beise-Zee, M. (2001), Lead Markets, Heidelberg/New York.

Berry, L.L., V. Shankar, J.T. Parish, S. Cadwallader and T. Dotzel (2006), Creating New Markets Through Service Innovation, MIT Sloan Management Review 47 (2), 56-63.

Bertrand, M. and S. Mullainathan (2001), Do People Mean What They Say? Implications for Subjective Survey Data, American Economic Review 91 (2), 67-72.

Bloom, N. and J. Van Reenen (2002), Patents, Real Options and Firm Performance, Economic Journal 112 (478), C97-C116.

Breschi, S., F. Malerba and L. Orsenigo (2000), Technological Regimes and Schumpeterian Patterns of Innovation, Economic Journal 110 (463), 388-410.

Calantone, R.J., J.B. Schmidt and C.A. Di Benedetto (1997), New Product Activities and Performance: The Moderating Role of Environmental Hostility, Journal of Product Innovation Management 14 (3), 179-189.

Cassiman, B. and R. Veugelers (2006), In Search of Complementarity in the Innovation Strategy: Internal R\&D and External Knowledge Acquisition, Management Science 52 (1), 68-82.

Chandy, R.K. and G.J. Tellis (2000), The incumbent's curse? Incumbency, Size and Radical Product Innovation, Journal of Marketing 64 (4), 1-17.

Chatterjee, S. and A.S. Hadi (2006), Regression Analysis by Example, New York.

Chatterji, D. (1996), Accessing External Sources of Technology, Technology Management 39 (2), 48-57.

Chesbrough, H.W. (2003), Open Innovation: The New Imperative for Creating and Profiting from Technology, Boston.

Cohen, W.M. and D.A. Levinthal (1989a), Innovation and Learning: The two Faces of R\&D, The Economic Journal 99 (397), 569-596.

Cohen, W.M. and D.A. Levinthal (1989b), Innovation and Learning: The two Faces of R\&D, The Economic Journal 99, 569-596.

Cohen, W.M. and D.A. Levinthal (1990), Absorptive Capacity: A New Perspective on Learning and Innovation, Administrative Science Quarterly 35 (1), 128-153. 
Cohen, W.M., R.R. Nelson and J.P. Walsh (2002), Links and Impacts: The Influence of Public Research on Industrial R\&D, Management Science 48 (1), 1-23.

Cowan, R., P.A. David and D. Foray (2000), The Explicit Economics of Knowledge Codification and Tacitness, Industrial and Corporate Change 9 (2), 211-254.

Criscuolo, C., J.E. Haskel and M.J. Slaughter (2005), Global Engagement and the Innovation Activities of Firms, NBER Working Paper No. 11479, Cambridge, MA.

Czarnitzki, D. and A. Toole (2007), Business R\&D and the Interplay of R\&D Subsidies and Product Market Uncertainty, Review of Industrial Organization 31 (3), 169-181.

Dewar, R.D. and J.E. Dutton (1986), The Adoption of Radical and Incremental Innovations: An Empirical Analysis, Management Science 32, 1422-1433.

Dolfsma, W. (2004), The Process Of New Service Development: Issues of Formalization and Appropriability, ERIM Report Series: Research In Management.

Doz, Y.L., J. Santos and P. Williamson (2001), From Global to Metanational: How Companies Win in the Knowledge Economy, Boston.

Dussauge, P., B. Garrette and W. Mitchell (2000), Learning from Competing Partners: Outcomes and Duration of Scale and Link Alliances in Europe, North America and Asia, Strategic Management Journal 21 (2), 99-126.

Dyer, J.H. and N.W. Hatch (2004), Using Supplier Networks to Learn Faster, Mit Sloan Management Review 45 (3), 57-63.

Dyer, J.H. and N.W. Hatch (2006), Relation-specific Capabilities and Barriers to Knowledge Transfers: Creating Advantage through Network Relationships, Strategic Management Journal 27 (8), 701-719.

Dyer, J.H., P. Kale and H. Singh (2001), How to Make Strategic Alliances Work, MIT Sloan Management Review 42 (4), 37-43.

Dyer, J.H. and H. Singh (1998), The Relational View: Cooperative Strategy and Sources of Interorganizational Competitive Advantage, Academy of Management Review 23 (4), 660-679.

Ettlie, J.E. (1983), Organizational Policy and Innovation among Suppliers to the Food Processing Sector, Academy of Management Journal 26, 27-44.

Eurostat (2005), Community Innovation Survey Light (CIS Light), http://europa.eu.int/estatref/info/sdds/de/inn/inn_cisl_sm.htm No., Luxemburg.

Frosch, R.A. (1996), The Customer for R\&D is Always Wrong!, Research Technology Management 39 (6), 22-25.

Gallini, N.T. (2002), The Economics of Patents: Lessons from Recent U.S. Patent Reform., Journal of Economic Perspectives 16 (2), 131-155.

Gallouj, F. (2002), Innovation in the Service Economy, Chaltenham, UK and Northhampton, MA, USA.

Galunic, C.D. and S. Rodan (1998), Resource Recombinations in the Firm: Knowledge Structures and the Potential for Schumpeterian, Strategic Management Journal 19 (12), 1193-1201.

Gatignon, H., M.L. Tushman, W. Smith and P. Anderson (2004), A Structural Approach to Assessing Innovation: Construct Development of Innovation Locus, Type and Characteristics, Management Science 48, 1103-1123.

Gemünden, H., M. Heydebreck and R. Wijnberg (1992), Technological Interweavement: A Means of Achieving Innovation Success, R\&D Management 22 (4), 359-376.

Gottschalk, S. and B. Peters (2009), Evaluation of the Usefulness of Anonymised CIS III data, published by Eurostat, for econometric analyses, ZEW Discussion Paper No. forthcoming, Mannheim.

Grant, R.M. (1996), Toward a Knowledge-Based Theory of the Firm, Strategic Management Journal 17, 109-122.

Greene, W.H. (2002), Econometric Analysis, New York. 
Griliches, Z. (1990), Patent Statistics as Economic Indicators: A Survey, Journal of Economic Literature 28 (4), 1661-1707.

Hagedoorn, J. and M. Cloodt (2003), Measuring Innovative Performance: Is There an Advantage in Using Multiple Indicators?, Research Policy 32, 1365-1379.

Harabi, N. (1995), Appropriability of Technological Innovations - An Empirical Analysis, Research Policy 24, 981-992.

Johne, A. and C. Storey (1998), New Service Development: A Review of the Literature and Annotated Bibliography, European Journal of Marketing 32 (3/4), 184-251.

Kaiser, H.F. and J. Rice (1974), Little Jiffy, Mark Iv, Educational and Psychological Measurement 34 (1), 111-117.

Kaiser, U. (2002), An Empirical Test of Models Explaining Research Expenditures and Research Co-operation: Evidence for the German Service Sector, International Journal of Industrial Organization 20, 747-774.

Katila, R. (2002), New Product Search Over Time: Past Ideas in Their Prime?, Academy of Management Journal 45 (5), 995-1010.

Katila, R. and G. Ahuja (2002), Something Old, Something New: A Longitudinal Study of Search Behavior and New Product Introduction, Academy of Management Journal 45 (6), 1183-1194.

Katila, R. and E.L. Chen (2008), Effects of Search Timing on Innovation: The Value of Not Being in Sync with Rivals, Administrative Science Quarterly 53 (4), 593-625.

Ketchen, D.J., G.T.M. Hult and S.F. Slater (2007), Toward greater Understanding of Market Orientation and the Resource-based View, Strategic Management Journal 28 (9), 961-964.

Kleinschmidt, E.J. and R.G. Cooper (1988), The Performance Impact of an International Orientation of Product Innovation, European Journal of Marketing 22 (10), 56-72.

Kogut, R. and U. Zander (1992), Knowledge of the Firm, Combinative Capabilities and the Replication of Technology, Organization Science 33 (3), 383-397.

Kohli, A.K. and B.J. Jaworski (1990), Market Orientation: The Construct, Research Propositions, and Managerial Implications, Journal of Marketing 54 (2), 1-18.

Koput, K.W. (1997), A Chaotic Model of Innovative Search: Some Answers, Many Questions, Organization Science 8 (5), 528-542.

Kotabe, M. (1990), The Relationship between Offshore Sourcing and Innovativeness of U.S. Multinational Firms: An Empirical Investigation, Journal of International Business Studies 21 (4), 623-638.

Lane, P.J. and M. Lubatkin (1998), Relative Absorptive Capacity and Inter-organizational Learning., Strategic Management Journal 19, 461-477.

Laursen, K. and A. Salter (2006), Open for Innovation: The Role of Openness in Explaining Innovation Performance among U.K. Manufacturing Firms, Strategic Management Journal 27 (2), 131-150.

Leiponen, A. and C.E. Helfat (forthcoming), Innovation Objectives, Knowledge Sources, and the Benefits of Breadth, Strategic Management Journal.

Liebeskind, J.P. (1996), Knowledge, Strategy, and the Theory of the Firm, Strategic Management Journal 17, 93-107.

Link, A.N. and J.T. Scott (2005), Universities as Partners in U.S. Research Joint Ventures, Research Policy 34, 385-393.

Link, A.N., D.S. Siegel and B. Bozeman (2006), An Empirical Analysis of the Propensity of Academics to Engage in Informal University Technology Transfer, Available at SSRN: http://ssrn.com/abstract=902207 No.,

Love, J.H. and S. Roper (2004), Knowledge Sourcing, Innovation and Performance: A Preliminary Analysis of Irish Innovation Panel Data, Aston Business School Working Paper No., Birmingham. 
Lukas, B.A. and O.C. Ferrell (2000), The Effect of Market Orientation on Product Innovation, Journal of the Academy of Marketing Science 28 (2), 239-247.

Lyons, R.K., J.A. Chatman and C.K. Joyce (2007), Innovation in Services: Corporate Culture and Investment Banking, California Management Review 50 (1), 174-191.

Macmillan, I., M.L. Mccaffery and G.v. Wijk (1985), Competitors' Responses to Easily Imitated New Products: Exploring Commercial Banking Product Introductions, Strategic Management Journal 6 (1), 75-86.

Maleri, R. (1997), Grundlagen der Dienstleistungsproduktion, Berlin.

Mansfield, E. (1986), Patents and Innovation: An Empirical Study, Management Science 32 (2), 173-181.

Mansfield, E., M. Schwartz and S. Wagner (1981), Imitation Costs and Patents: An Empirical Study, The Economic Journal 91, 907-918.

March, J.G. and Z. Shapira (1987), Managerial Perspectives on Risk and Risk Taking, Management Science 33 (11), 1404-1418.

Miozzo, M. and L. Soete (2001), Internationalization of Services: A Technological Perspective, Technological Change and Social Forecasting 67, 159-185.

Nelson, R.R. and S.G. Winter (1982), An Evolutionary Theory of Economic Change, Cambridge, MA.

Ocasio, W. (1997), Towards an Attention-Based View of the Firm, Strategic Management Journal 18, 187-206.

OECD (2006), Science, Technology and Industry Outlook, Paris.

Ojah, K. and L. Monplaisir (2003), Investors' Valuation of Global Product Design and Development, Journal of International Business Studies 34, 457-472.

Paswan, A., D. D'Souza and M.A. Zolfagharian (2009), Toward a Contextually Anchored Service Innovation Typology, Decision Sciences 40 (3), 513-540.

Pavitt, K. (1984), Sectoral Patterns of Technical Change: Towards a Taxonomy and a Theory, Research Policy 13 (6), 343-373.

Perkmann, M. and K. Walsh (2007), University-Industry Relationships and Open Innovation: Towards a Research Agenda, International Journal of Management Reviews 9 (4), 259-280.

Polanyi, M. (1967), The Tacit Dimension., Garden City, NY.

Rammer, C., D. Czarnitzki and A. Spielkamp (2009), Innovation Success of Non-R\&DPerformers: Substituting Technology by Management in SMEs, Small Business Economics 33 (1), 35-58.

Romer, P.M. (1990), Endogenous Technological Change, Journal of Political Economy 98 (5), 71-102.

Rosenkopf, L. and A. Nerkar (2001), Beyond Local Search: Boundary-Spanning, Exploration, and Impact in the Optical Disc Industry, Strategic Management Journal 22 (4), 287-306.

Scholich, M., R. Gleich and H. Grobusch (2006), Innovation Performance: Das Geheimnis erfolgreicher Dienstleister, Frankfurt.

Siegel, D.S., D.A. Waldman, L.E. Atwater and A.N. Link (2004), Toward a Model of the Effective Transfer of Scientific Knowledge from Academicians to Practitioners: Qualitative Evidence from the Commercialization of University Technologies, Journal of Engineering and Technology Management 21 (1-2), 115-142.

Sirilli, G. and R. Evangelista (1998), Technological Innovation in Services and Manufacturing: Results from Italian Surveys, Research Policy 27, 881-899.

Slater, S.F. and J.C. Narver (1998), Customer-Led and Market-Oriented: Let's Not Confuse the Two, Strategic Management Journal 19 (10), 1001.

Slater, S.F. and J.C. Narver (1999), Market-Oriented is More Than Being Customer-Led, Strategic Management Journal 20 (12), 1165-1168. 
Slater, S.F. and J.C. Narver (2000), The Positive Effect of a Market Orientation on Business Profitability: A Balanced Replication, Journal of Business Research 48 (1), 69-73.

Subramaniam, M. and N. Venkatraman (2001), Determinants of Transnational New Product Development Capability: Testing the Influence of Transferring and Deploying Tacit Overseas Knowledge, Strategic Management Journal 22, 359-378.

Subramaniam, M. and M.A. Youndt (2005), The Influence of Intellectual Capital on the Types of Innovative Capabilities, Academy of Management Journal 48 (3), 450-463.

Szulanski, G. (1996), Exploring Internal Stickiness: Impediments to the Transfer of Best Practice Within the Firm, Strategic Management Journal 17 (Special issue), 27-43.

Szulanski, G. (2000), The Process of Knowledge Transfer: A Diachronic Analysis of Stickiness, Organizational Behavior \& Human Decision Processes 82 (1), 9-27.

Teece, D.J., G. Pisano and A. Shuen (1997), Dynamic Capabilities and Strategic Management, Strategic Management Journal 18 (7), 509-533.

Todorova, G. and B. Durisin (2007), Absorptive Capacity: Valuing a Reconceptualization, Academy of Management Review 32 (3), 774-786.

van Echtelt, F.E.A., F. Wynstra, A.J. van Weele and G. Duysters (2008), Managing Supplier Involvement in New Product Development: A Multiple-Case Study, Journal of Product Innovation Management 25, 180-201.

von Hippel, E. (1988), The Sources of Innovation, New York.

Zedtwitz, M. and O. Gassmann (2002), Managing Customer Oriented Research, International Journal of Technology Management 24 (2/3), 165-193. 


\section{Appendix}

\section{Appendix A: Descriptive statistics by search strategy}

\begin{tabular}{|c|c|c|c|c|c|c|c|c|c|c|c|}
\hline & \multicolumn{2}{|c|}{ All firms } & \multicolumn{3}{|c|}{$\begin{array}{c}\text { Science-driven search used } \\
\text { above average }\end{array}$} & \multicolumn{3}{|c|}{$\begin{array}{c}\text { Supplier-driven search used } \\
\text { above average }\end{array}$} & \multicolumn{3}{|c|}{$\begin{array}{c}\text { Market-driven search usec } \\
\text { above average }\end{array}$} \\
\hline & Mean & Std. Dev. & Mean & & Std. Dev. & Mean & & Std. Dev. & Mean & & Std. Dev. \\
\hline $\begin{array}{l}\text { Share of sales with } \\
\text { market novelties }\end{array}$ & 0.101 & 0.180 & 0.110 & $\star \star \star$ & 0.179 & 0.104 & & 0.180 & 0.104 & & 0.177 \\
\hline $\begin{array}{l}\text { Share of sales with firm } \\
\text { novelties }\end{array}$ & 0.159 & 0.236 & 0.168 & ** & 0.229 & 0.159 & & 0.234 & 0.169 & 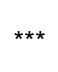 & 0.231 \\
\hline $\begin{array}{l}\text { Science-driven search } \\
\text { strategy (scale) }\end{array}$ & 0.000 & 1.000 & 1.046 & $\star \star \star ~$ & 0.801 & 0.039 & $\star \star *$ & 1.053 & 0.013 & & 1.006 \\
\hline $\begin{array}{l}\text { Supplier-driven search } \\
\text { strategy (scale) }\end{array}$ & 0.000 & 1.000 & 0.127 & $\star \star \star$ & 0.926 & 0.798 & $\star \star *$ & 0.544 & 0.003 & & 0.934 \\
\hline $\begin{array}{l}\text { Market-driven search } \\
\text { strategy (scale) }\end{array}$ & 0.000 & 1.000 & 0.119 & 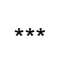 & 0.942 & 0.034 & $\star \star \star *$ & 0.982 & 0.817 & $\star * *$ & 0.518 \\
\hline $\begin{array}{l}\text { Share of internal R\&D } \\
\text { exp. of sales (ratio) }\end{array}$ & 0.024 & 0.082 & 0.039 & $\star \star \star *$ & 0.110 & 0.026 & ** & 0.087 & 0.027 & $\star * \star$ & 0.083 \\
\hline Cont. R\&D activities (d) & 0.421 & 0.494 & 0.614 & $\star \star \star *$ & 0.487 & 0.451 & $* * *$ & 0.498 & 0.485 & $* * *$ & 0.500 \\
\hline $\begin{array}{l}\text { Share of sales w/ exports } \\
\text { (ratio) }\end{array}$ & 0.210 & 0.279 & 0.264 & $\star \star \star$ & 0.296 & 0.212 & & 0.280 & 0.234 & $\star * *$ & 0.284 \\
\hline Sales $1998(\log )$ & 15.963 & 1.977 & 16.485 & $\star \star \star$ & 2.087 & 16.002 & * & 1.960 & 16.150 & $\star * *$ & 1.997 \\
\hline $\begin{array}{l}\text { Part of company group } \\
\text { (d) }\end{array}$ & 0.459 & 0.498 & 0.553 & $\star \star \star ~$ & 0.497 & 0.435 & & 0.496 & 0.484 & $\star * \star$ & 0.500 \\
\hline Process innovation (d) & 0.648 & 0.478 & 0.693 & $\star \star \star *$ & 0.461 & 0.689 & $* * *$ & 0.463 & 0.641 & & 0.480 \\
\hline Greece (d) & 0.066 & 0.249 & 0.038 & & 0.192 & 0.070 & & 0.256 & 0.048 & & 0.214 \\
\hline Portugal (d) & 0.100 & 0.300 & 0.076 & & 0.266 & 0.106 & ** & 0.308 & 0.079 & & 0.270 \\
\hline Spain (d) & 0.410 & 0.492 & 0.418 & & 0.493 & 0.396 & & 0.489 & 0.375 & & 0.484 \\
\hline Germany (d) & 0.296 & 0.456 & 0.333 & $\star \star \star *$ & 0.471 & 0.310 & ** & 0.463 & 0.374 & $* * *$ & 0.484 \\
\hline Belgium (d) & 0.128 & 0.334 & 0.135 & & 0.342 & 0.118 & & 0.322 & 0.124 & & 0.330 \\
\hline $\begin{array}{l}\text { Low-tech manufacturing } \\
\text { (d) }\end{array}$ & 0.268 & 0.443 & 0.217 & & 0.412 & 0.297 & $\star \star \star$ & 0.457 & 0.222 & & 0.416 \\
\hline $\begin{array}{l}\text { Medium Low-tech } \\
\text { manufacturing }(d)\end{array}$ & 0.181 & 0.385 & 0.184 & & 0.387 & 0.179 & & 0.383 & 0.178 & & 0.382 \\
\hline $\begin{array}{l}\text { Medium High-tech } \\
\text { manufacturing }(d)\end{array}$ & 0.213 & 0.409 & 0.251 & $\star \star \star *$ & 0.434 & 0.208 & & 0.406 & 0.240 & $\star * \star$ & 0.427 \\
\hline $\begin{array}{l}\text { High-tech } \\
\text { manufacturing (d) }\end{array}$ & 0.058 & 0.235 & 0.075 & $\star \star \star \star ~$ & 0.263 & 0.061 & & 0.240 & 0.078 & $\star \star \star$ & 0.269 \\
\hline $\begin{array}{l}\text { Low knowl.-int. services } \\
\text { (d) }\end{array}$ & 0.105 & 0.307 & 0.062 & & 0.240 & 0.091 & & 0.288 & 0.098 & & 0.297 \\
\hline Knowl.-int. services (d) & 0.175 & 0.380 & 0.212 & $\star \star \star ~$ & 0.409 & 0.163 & & 0.370 & 0.184 & ** & 0.388 \\
\hline $\mathrm{N}$ & 5,010 & & 1,966 & & & 2,576 & & & 2,568 & & \\
\hline
\end{tabular}

(d) Dummy variable, $* \mathrm{p}<0.10, * * \mathrm{p}<0.05, * * * \mathrm{p}<0.01$

A T-Test is computed in comparison to firms using the respective search strategy below the average. 
Appendix B: Coefficients of country and industry dummies

\begin{tabular}{|c|c|c|c|c|}
\hline & \multicolumn{2}{|c|}{ Full sample } & \multicolumn{2}{|c|}{ Service sample } \\
\hline & $\begin{array}{c}\text { Share of sales } \\
\text { with firm } \\
\text { novelties }\end{array}$ & $\begin{array}{c}\text { Share of sales } \\
\text { with market } \\
\text { novelties }\end{array}$ & $\begin{array}{c}\text { Share of sales } \\
\text { with firm } \\
\text { novelties }\end{array}$ & $\begin{array}{c}\text { Share of sales } \\
\text { with market } \\
\text { novelties }\end{array}$ \\
\hline & I & II & III & IV \\
\hline Greece (d) & $\begin{array}{c}-0.063 * * \\
(0.031)\end{array}$ & $\begin{array}{l}-0.015 \\
(0.036)\end{array}$ & $\begin{array}{l}-0.074 \\
(0.054)\end{array}$ & $\begin{array}{l}0.015 \\
(0.063)\end{array}$ \\
\hline Portugal (d) & $\begin{array}{c}-0.085 * * * \\
(0.022)\end{array}$ & $\begin{array}{c}0.107 * * * \\
(0.021)\end{array}$ & $\begin{array}{c}-0.189 * * * \\
(0.058)\end{array}$ & $\begin{array}{l}0.041 \\
(0.061)\end{array}$ \\
\hline Spain (d) & $\begin{array}{c}0.109 * * * \\
(0.015)\end{array}$ & $\begin{array}{c}0.081 * * * \\
(0.016)\end{array}$ & $\begin{array}{l}0.032 \\
(0.029)\end{array}$ & $\begin{array}{l}0.054 \\
(0.033)\end{array}$ \\
\hline Germany $(d)$ & $\begin{array}{c}0.057 * * * \\
(0.014)\end{array}$ & $\begin{array}{c}0.060 * * * \\
(0.016)\end{array}$ & $\begin{array}{l}0.025 \\
(0.024)\end{array}$ & $\begin{array}{l}0.029 \\
(0.031)\end{array}$ \\
\hline Medium Low-tech manufacturing (d) & $\begin{array}{l}0.023 \\
(0.015)\end{array}$ & $\begin{array}{l}0.011 \\
(0.013)\end{array}$ & & \\
\hline Medium High-tech manufacturing (d) & $\begin{array}{c}0.037 * * \\
(0.015)\end{array}$ & $\begin{array}{c}0.026 * * \\
(0.013)\end{array}$ & & \\
\hline High-tech manufacturing (d) & $\begin{array}{c}0.068 * * * \\
(0.023)\end{array}$ & $\begin{array}{c}0.069 * * * \\
(0.018)\end{array}$ & & \\
\hline Low knowl.-int. services (d) & $\begin{array}{l}0.006 \\
(0.019)\end{array}$ & $\begin{array}{r}-0.013 \\
(0.019)\end{array}$ & $\begin{array}{c}-0.032 \\
(0.019)\end{array}$ & $\begin{array}{c}-0.048 * * * \\
(0.019)\end{array}$ \\
\hline Knowl.-int. services (d) & $\begin{array}{c}0.035^{* *} \\
(0.017)\end{array}$ & $\begin{array}{c}0.043 * * * \\
(0.015)\end{array}$ & & \\
\hline
\end{tabular}

(d) Dummy variable, ${ }^{*} \mathrm{p}<0.10,{ }^{* *} \mathrm{p}<0.05,{ }^{* * *} \mathrm{p}<0.01$; standard error in parentheses. 


\section{Appendix C: Coefficients of Tobit models including squared search strategy variables}

\begin{tabular}{|c|c|c|c|c|}
\hline & Fulls & ample & Service & sample \\
\hline & $\begin{array}{c}\text { Share of sales } \\
\text { with firm } \\
\text { novelties }\end{array}$ & $\begin{array}{c}\text { Share of sales } \\
\text { with market } \\
\text { novelties }\end{array}$ & $\begin{array}{c}\text { Share of sales } \\
\text { with firm } \\
\text { novelties }\end{array}$ & $\begin{array}{c}\text { Share of sales } \\
\text { with market } \\
\text { novelties }\end{array}$ \\
\hline & I & II & III & IV \\
\hline Science-driven search strategy (scale) & $\begin{array}{c}0.118 \\
(0.083)\end{array}$ & $\begin{array}{c}0.093 \\
(0.068)\end{array}$ & $\begin{array}{c}0.387 * * \\
(0.157)\end{array}$ & $\begin{array}{c}0.181 \\
(0.135)\end{array}$ \\
\hline Supplier-driven search strategy (scale) & $\begin{array}{c}0.005 \\
(0.107)\end{array}$ & $\begin{array}{c}0.121 \\
(0.093)\end{array}$ & $\begin{array}{c}0.131 \\
(0.194)\end{array}$ & $\begin{array}{c}0.044 \\
(0.180)\end{array}$ \\
\hline Market-driven search strategy (scale) & $\begin{array}{l}0.107 \\
(0.087)\end{array}$ & $\begin{array}{l}-0.024 \\
(0.076)\end{array}$ & $\begin{array}{c}0.207 \\
(0.162)\end{array}$ & $\begin{array}{c}0.068 \\
(0.146)\end{array}$ \\
\hline Squared science-driven search strategy (scale) & $\begin{array}{l}-0.125 \\
(0.099)\end{array}$ & $\begin{array}{l}-0.069 \\
(0.080)\end{array}$ & $\begin{array}{c}-0.376^{* *} \\
(0.190)\end{array}$ & $\begin{array}{l}-0.097 \\
(0.159)\end{array}$ \\
\hline Squared supplier-driven search strategy (scale) & $\begin{array}{c}0.015 \\
(0.104)\end{array}$ & $\begin{array}{l}-0.085 \\
(0.091)\end{array}$ & $\begin{array}{l}-0.150 \\
(0.194)\end{array}$ & $\begin{array}{c}0.038 \\
(0.178)\end{array}$ \\
\hline Squared market-driven search strategy (scale) & $\begin{array}{c}0.015 \\
(0.084)\end{array}$ & $\begin{array}{c}0.049 \\
(0.072)\end{array}$ & $\begin{array}{l}-0.114 \\
(0.154)\end{array}$ & $\begin{array}{c}0.006 \\
(0.136)\end{array}$ \\
\hline Share of internal R\&D exp. of sales (ratio) & $\begin{array}{l}0.131^{*} \\
(0.069)\end{array}$ & $\begin{array}{c}0.310^{* * * *} \\
(0.061)\end{array}$ & $\begin{array}{c}0.124 \\
(0.084)\end{array}$ & $\begin{array}{c}0.231 * * * \\
(0.071)\end{array}$ \\
\hline Continuous R\&D activities (d) & $\begin{array}{c}0.030^{* * * *} \\
(0.011)\end{array}$ & $\begin{array}{c}0.081 * * * \\
(0.009)\end{array}$ & $\begin{array}{c}0.030 \\
(0.020)\end{array}$ & $\begin{array}{c}0.085^{* * *} * \\
(0.018)\end{array}$ \\
\hline Share of sales w/ exports (ratio) & $\begin{array}{c}0.017 \\
(0.019)\end{array}$ & $\begin{array}{c}0.042 * * * \\
(0.016)\end{array}$ & $\begin{array}{l}-0.063 \\
(0.044)\end{array}$ & $\begin{array}{l}-0.042 \\
(0.044)\end{array}$ \\
\hline Sales $1998(\log )$ & $\begin{array}{c}0.003 \\
(0.003)\end{array}$ & $\begin{array}{c}0.002 \\
(0.002)\end{array}$ & $\begin{array}{l}-0.001 \\
(0.004)\end{array}$ & $\begin{array}{c}0.001 \\
(0.004)\end{array}$ \\
\hline Part of company group (d) & $\begin{array}{l}-0.007 \\
(0.011)\end{array}$ & $\begin{array}{c}0.003 \\
(0.009)\end{array}$ & $\begin{array}{l}0.034^{*} \\
(0.019)\end{array}$ & $\begin{array}{l}-0.023 \\
(0.017)\end{array}$ \\
\hline Process innovation $(\mathrm{d})$ & $\begin{array}{c}-0.057 * * * \\
(0.010)\end{array}$ & $\begin{array}{l}-0.003 \\
(0.009)\end{array}$ & $\begin{array}{c}-0.046^{* *} \\
(0.018)\end{array}$ & $\begin{array}{l}-0.019 \\
(0.017)\end{array}$ \\
\hline Greece (d) & $\begin{array}{c}-0.063 * * \\
(0.031)\end{array}$ & $\begin{array}{l}-0.013 \\
(0.036)\end{array}$ & $\begin{array}{l}-0.074 \\
(0.055)\end{array}$ & $\begin{array}{c}0.016 \\
(0.063)\end{array}$ \\
\hline Portugal (d) & $\begin{array}{c}-0.085 * * * \\
(0.022)\end{array}$ & $\begin{array}{c}0.107 * * * \\
(0.021)\end{array}$ & $\begin{array}{c}-0.193 * * * \\
(0.059)\end{array}$ & $\begin{array}{c}0.042 \\
(0.061)\end{array}$ \\
\hline Spain (d) & $\begin{array}{c}0.109 * * * \\
(0.015)\end{array}$ & $\begin{array}{c}0.082 * * * \\
(0.016)\end{array}$ & $\begin{array}{l}0.030 \\
(0.028)\end{array}$ & $\begin{array}{c}0.053 \\
(0.033)\end{array}$ \\
\hline Germany (d) & $\begin{array}{c}0.057 * * * \\
(0.014)\end{array}$ & $\begin{array}{c}0.060 * * * \\
(0.016)\end{array}$ & $\begin{array}{c}0.019 \\
(0.024)\end{array}$ & $\begin{array}{c}0.028 \\
(0.031)\end{array}$ \\
\hline Medium Low-tech manufacturing (d) & $\begin{array}{c}0.022 \\
(0.015)\end{array}$ & $\begin{array}{c}0.011 \\
(0.013)\end{array}$ & & \\
\hline Medium High-tech manufacturing (d) & $\begin{array}{c}0.036^{* *} \\
(0.015)\end{array}$ & $\begin{array}{l}0.025^{*} \\
(0.013)\end{array}$ & & \\
\hline High-tech manufacturing $(\mathrm{d})$ & $\begin{array}{c}0.067 * * * \\
(0.023)\end{array}$ & $\begin{array}{c}0.067 * * * \\
(0.018)\end{array}$ & & \\
\hline Low knowl.-int. services (d) & $\begin{array}{l}0.006 \\
(0.019)\end{array}$ & $\begin{array}{l}-0.013 \\
(0.019)\end{array}$ & $\begin{array}{l}-0.028 \\
(0.020)\end{array}$ & $\begin{array}{c}-0.048 * * * \\
(0.019)\end{array}$ \\
\hline Knowl.-int. services $(\mathrm{d})$ & $\begin{array}{c}0.034^{* *} \\
(0.017)\end{array}$ & $\begin{array}{c}0.042 * * * \\
(0.015)\end{array}$ & & \\
\hline Constant & $\begin{array}{c}-0.110 * * \\
(0.054)\end{array}$ & $\begin{array}{c}-0.237 * * * \\
(0.047) \\
\end{array}$ & $\begin{array}{l}-0.071 \\
(0.086) \\
\end{array}$ & $\begin{array}{c}-0.160 * * \\
(0.078) \\
\end{array}$ \\
\hline $\begin{array}{l}\text { Wald - Test on joint significance of } \\
\text { industry dummies }\end{array}$ & $\begin{array}{c}\mathrm{W}\left(\chi^{2}(10)\right)= \\
18.45^{* *}\end{array}$ & $\begin{array}{l}\mathrm{W}\left(\chi^{2}(10)\right)= \\
43.30^{* * *}\end{array}$ & $\begin{array}{l}\mathrm{W}\left(\chi^{2}(2)\right)= \\
2.05\end{array}$ & $\begin{array}{l}\mathrm{W}\left(\chi^{2}(2)\right)= \\
9.05^{* *}\end{array}$ \\
\hline Aldrich-Nelson Pseudo- $\mathrm{R}^{2}$ & 0.21 & 0.26 & 0.24 & 0.34 \\
\hline Log likelihood & -2207.622 & -1770.377 & -606.927 & -530.599 \\
\hline No. of observations & 5,010 & 5,010 & 1,401 & 1,401 \\
\hline LR - Test on heteroscedasticity & $\begin{array}{l}\operatorname{LR}\left(\chi^{2}(10)\right)= \\
216.487 * * *\end{array}$ & $\begin{array}{l}\operatorname{LR}\left(\chi^{2}(10)\right)= \\
328.202 * * *\end{array}$ & $\begin{array}{l}\operatorname{LR}\left(\chi^{2}(6)\right)= \\
96.957 * * *\end{array}$ & $\begin{array}{l}\operatorname{LR}\left(\chi^{2}(6)\right)= \\
100.158^{* * *}\end{array}$ \\
\hline
\end{tabular}

(d) Dummy variable, $* \mathrm{p}<0.10, * * \mathrm{p}<0.05, * * * \mathrm{p}<0.01$; standard errors in parentheses.

Search strategy scales are rescaled between 0 and 1 .

Heteroscedasticity term includes firm size as measured by sales in $1998(\log ), 4$ country dummies and 5 industry dummies (Service sample:

1 industry dummy). 
Appendix D: Correlation Matrix and Variance Inflation Factors

\begin{tabular}{|c|c|c|c|c|c|c|c|c|c|c|c|c|c|c|c|c|c|c|}
\hline & $\begin{array}{l}\text { Science- } \\
\text { driven } \\
\text { search } \\
\text { strategy } \\
\text { (scale) }\end{array}$ & $\begin{array}{l}\text { Supplier- } \\
\text { driven } \\
\text { search } \\
\text { strategy } \\
\text { (scale) }\end{array}$ & $\begin{array}{l}\text { Market- } \\
\text { driven } \\
\text { search } \\
\text { strategy } \\
\text { (scale) }\end{array}$ & $\begin{array}{c}\text { Share of } \\
\text { int. R\&D } \\
\text { exp. of } \\
\text { sales } \\
\text { (ratio) }\end{array}$ & $\begin{array}{c}\text { Cont. } \\
\text { R\&D } \\
\text { activities } \\
\text { (d) }\end{array}$ & $\begin{array}{l}\text { Share of } \\
\text { sales w/ } \\
\text { exports } \\
\text { (ratio) }\end{array}$ & $\begin{array}{l}\text { Sales } \\
1998 \\
(\log )\end{array}$ & $\begin{array}{l}\text { Part of } \\
\text { company } \\
\text { group (d) }\end{array}$ & $\begin{array}{l}\text { Process } \\
\text { innova- } \\
\text { tion (d) }\end{array}$ & $\begin{array}{l}\text { Greece } \\
\text { (d) }\end{array}$ & $\begin{array}{l}\text { Portugal } \\
\text { (d) }\end{array}$ & $\begin{array}{l}\text { Spain } \\
\text { (d) }\end{array}$ & $\begin{array}{l}\text { Germany } \\
\text { (d) }\end{array}$ & $\begin{array}{l}\text { Medium } \\
\text { Low-tech } \\
\text { manuf. } \\
\text { (d) }\end{array}$ & $\begin{array}{l}\text { Medium } \\
\text { High- } \\
\text { tech } \\
\text { manuf. } \\
\text { (d) }\end{array}$ & $\begin{array}{l}\text { High- } \\
\text { tech } \\
\text { manuf. } \\
\text { (d) }\end{array}$ & $\begin{array}{l}\text { Low } \\
\text { knowl.- } \\
\text { int. } \\
\text { services } \\
\text { (d) }\end{array}$ & $\begin{array}{l}\text { Knowl.- } \\
\text { int. } \\
\text { services } \\
\text { (d) }\end{array}$ \\
\hline $\begin{array}{l}\text { Science-driven search } \\
\text { strategy (scale) }\end{array}$ & 1 & & & & & & & & & & & & & & & & & \\
\hline $\begin{array}{c}\text { Supplier-driven search } \\
\text { strategy (scale) }\end{array}$ & 0 & 1 & & & & & & & & & & & & & & & & \\
\hline $\begin{array}{c}\text { Market-driven search } \\
\text { strategy (scale) }\end{array}$ & 0 & 0 & 1 & & & & & & & & & & & & & & & \\
\hline $\begin{array}{c}\text { Share of internal R\&D } \\
\text { exp. of sales (ratio) }\end{array}$ & 0.216 & 0.019 & 0.041 & 1 & & & & & & & & & & & & & & \\
\hline $\begin{array}{c}\text { Continous R\&D } \\
\text { activities (d) }\end{array}$ & 0.327 & 0.057 & 0.161 & 0.263 & 1 & & & & & & & & & & & & & \\
\hline $\begin{array}{l}\text { Share of sales w/ } \\
\text { exports (ratio) }\end{array}$ & 0.140 & 0.004 & 0.108 & 0.013 & 0.266 & 1 & & & & & & & & & & & & \\
\hline Sales $1998(\log )$ & 0.195 & 0.004 & 0.105 & -0.109 & 0.283 & 0.272 & 1 & & & & & & & & & & & \\
\hline $\begin{array}{l}\text { Part of company } \\
\text { group (d) }\end{array}$ & 0.156 & -0.061 & 0.059 & -0.008 & 0.191 & 0.178 & 0.477 & 1 & & & & & & & & & & \\
\hline Process innovation (d) & 0.064 & 0.118 & -0.019 & -0.030 & 0.082 & 0.058 & 0.147 & 0.071 & 1 & & & & & & & & & \\
\hline Greece (d) & -0.080 & 0.046 & -0.097 & -0.077 & -0.093 & -0.200 & -0.184 & -0.140 & 0.022 & 1 & & & & & & & & \\
\hline Portugal (d) & -0.060 & 0.028 & -0.092 & -0.073 & -0.112 & 0.046 & -0.082 & -0.034 & 0.102 & -0.089 & 1 & & & & & & & \\
\hline Spain (d) & 0.025 & -0.056 & -0.083 & 0.063 & -0.005 & -0.055 & -0.044 & -0.031 & -0.069 & -0.223 & -0.278 & 1 & & & & & & \\
\hline Germany (d) & 0.054 & 0.038 & 0.220 & -0.009 & 0.106 & -0.044 & 0.188 & 0.035 & 0.005 & -0.173 & -0.216 & -0.541 & 1 & & & & & \\
\hline $\begin{array}{l}\text { Medium Low-tech } \\
\text { manufacturing }(d)\end{array}$ & -0.005 & -0.002 & -0.007 & -0.087 & -0.035 & 0.051 & -0.023 & -0.008 & 0.025 & 0.025 & 0.003 & -0.001 & -0.001 & 1 & & & & \\
\hline $\begin{array}{l}\text { Medium High-tech } \\
\text { manufacturing }(d)\end{array}$ & 0.067 & -0.011 & 0.082 & -0.016 & 0.177 & 0.265 & 0.132 & 0.051 & 0.006 & -0.062 & -0.004 & -0.070 & 0.059 & -0.244 & 1 & & & \\
\hline $\begin{array}{c}\text { High-tech } \\
\text { manufacturing (d) }\end{array}$ & 0.060 & 0.001 & 0.097 & 0.068 & 0.150 & 0.088 & -0.016 & 0.002 & -0.053 & -0.056 & -0.038 & 0.048 & 0.014 & -0.117 & -0.130 & 1 & & \\
\hline $\begin{array}{l}\text { Low knowl.-int. } \\
\text { services (d) }\end{array}$ & -0.111 & -0.038 & -0.029 & -0.080 & -0.168 & -0.150 & 0.018 & 0.040 & -0.012 & 0.013 & 0.012 & -0.122 & 0.058 & -0.161 & -0.178 & -0.085 & 1 & \\
\hline $\begin{array}{l}\text { Knowl.-int. services } \\
\text { (d) }\end{array}$ & 0.102 & -0.043 & 0.031 & 0.278 & 0.047 & -0.216 & -0.069 & 0.070 & -0.031 & -0.024 & -0.076 & -0.025 & 0.075 & -0.216 & -0.239 & -0.115 & -0.158 & 1 \\
\hline VIF & 1.19 & 1.04 & 1.10 & 1.25 & 1.41 & 1.41 & 1.59 & 1.37 & 1.06 & 1.63 & 1.70 & 2.78 & 2.63 & 1.41 & 1.57 & 1.23 & 1.35 & 1.63 \\
\hline Mean VIF & 1.52 & & & & & & & & & & & & & & & & & \\
\hline No. of observations & 5,010 & & & & & & & & & & & & & & & & & \\
\hline
\end{tabular}

(d) Dummy variable, VIF: Variance Inflation Factor 